\title{
口腔二現ハレタル扁本紅色苔旅 並二口腔徽毒二就厅
}

Dr. Mamoru Ogata: Über Lichen ruber planus und plaque muqueuse an Mundhöhleschleimhaut.

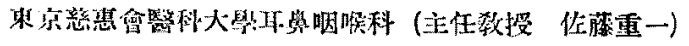

貥手应

形电

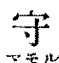

次

目

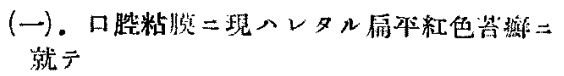

12. 治 祭 江

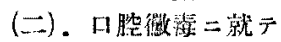

$\begin{array}{ll}\text { I. 緒 } & \text { 言 } \\ \text { II. 淀 } & \text { 例 } \\ \text { III. 考 } & \text { 案 }\end{array}$

1. 文谁/概略

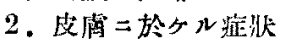

3. 粘膜二於々儿堽留

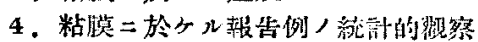

5. 病原 諭

6. 年额及ビ性别

7. 好新部位

8. 㥅生菜

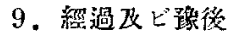

10. 会例証

11. 将全理
I. 緒言

II. 症例

III. 考菜

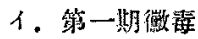

口. 第二期徽毒

八. 第三期徵声

二. 余八漹例二對スル考察

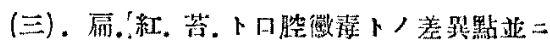

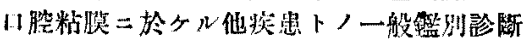

二影テ

(四)、結論

(五)。支补

(空). 附 問

\section{（一）口腔粘膜二現ハレタル扁平紶色苔癄二就テ}

\section{I. 緒言}

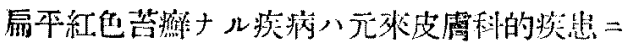
シテ 1869 年 Wilsen 初ヌデフ記能セリ。本症

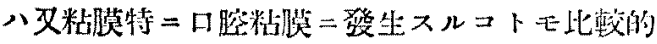
震 $\mathbf{1}$ 上ニ及ブト云フ。然王吾か国耳稛咽哓科界二於

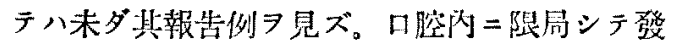

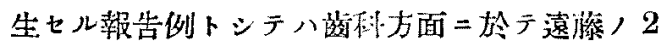

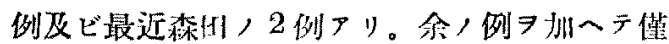

カ 5 例二邀ギ

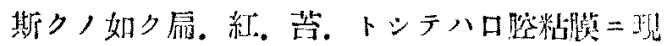

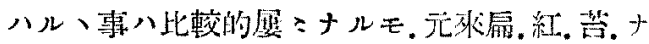

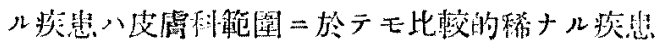

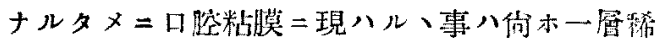

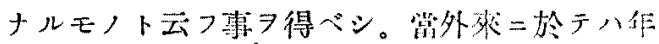
=1例 7 胃ル力見ナ1カ，程度二過ギザル所

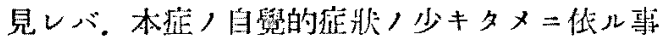

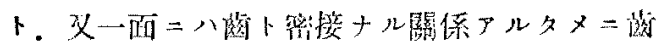




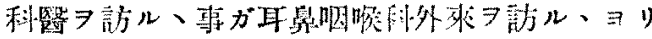
遥クニ多手事情二依ルモノナラント思八ル。 然气此奖患八一度斯カル例＝遭遇シ其局所所見

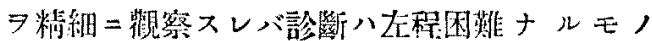
ナラザルモ。時トシラ貒請性疢態及八結核性病

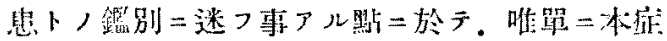
，自學的㱏状／少キタメ卜治等經過，長ク然

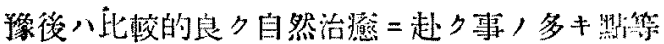

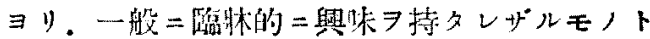

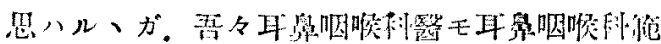

\section{II. 症}

\section{拉例}

艎者 48歳，父子。

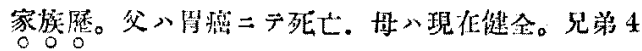

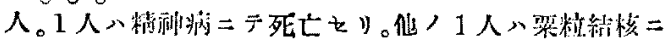

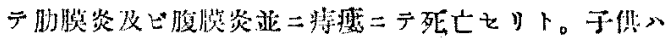

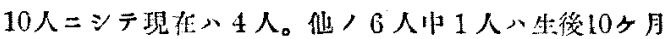

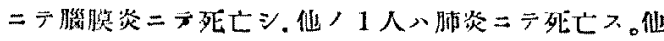

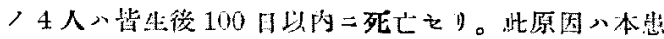

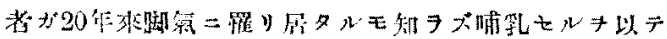

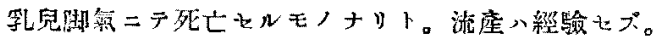

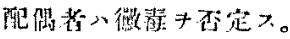

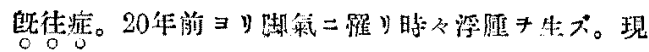

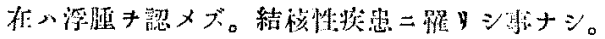

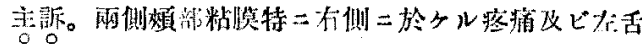
下缘人疼痛。

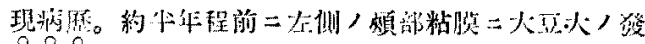

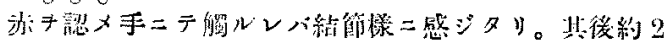

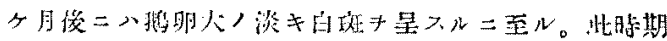

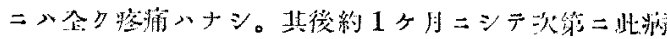

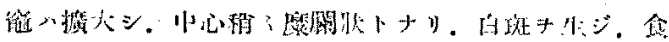

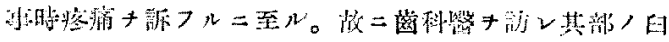

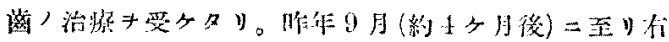

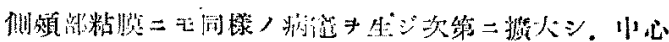

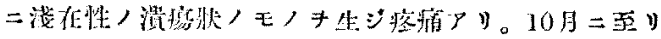

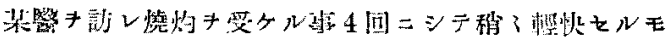

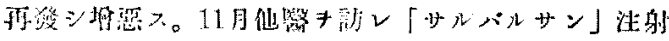

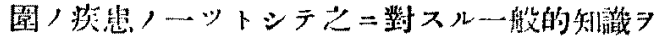
有スルコト八必姴ナル事ト思ヒ。最近余モ嘚。

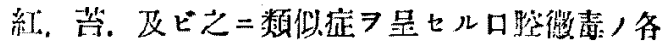
1 例二邈遇七ル

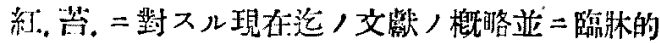
弯項二就キ余／知り得タル所 洔二口陵倶青， 1 例 7 附加シ. 兩者 7 比較シ。

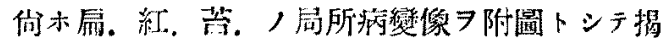
ダ諸蜸，御参考ノ資二俱スル次第ナリ。

例

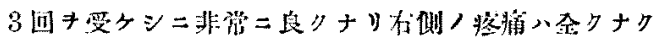

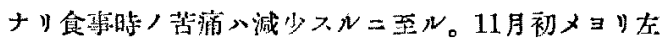

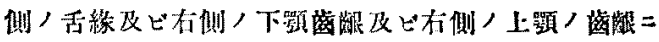

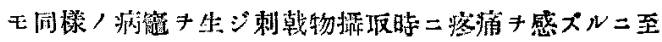

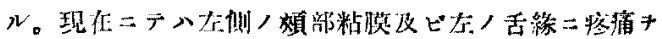
被フ。

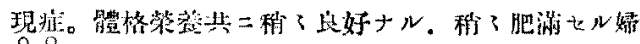

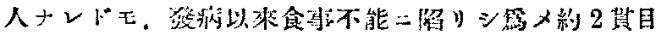

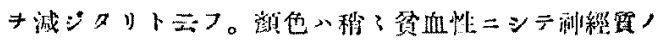

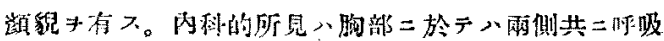

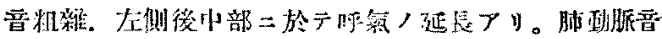

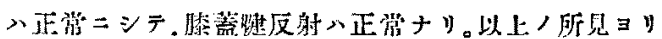

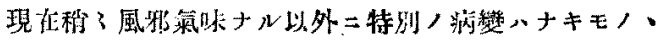

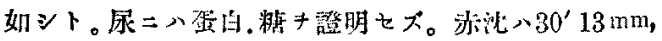
$1 \mathrm{st} 26 \mathrm{~mm}, 2 \mathrm{st} 51 \mathrm{~mm}=シ テ$ 稍、速キモ。當点患老

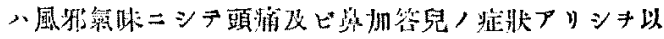
テ赤沈速废元猴せルモノナラン。

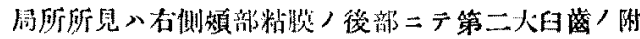

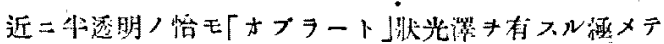

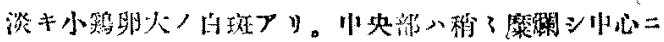

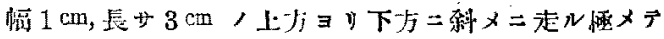

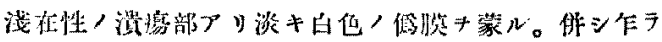

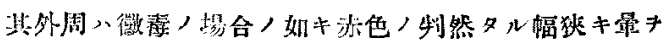

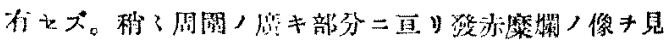

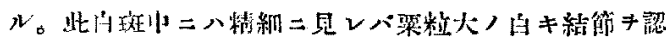

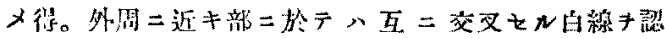




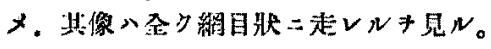

左侧煩部粘摸モ第

二大日菌，部二於 テハ稍、著白ニシ テ昌キ緗キ線ノ放 射狀二走レルノま 見，粘獏八稍：粚 穕々ルヤ二見 社夫とヨリ前方 ニシテ第二小目䔄 位迄八粘膜八棉卵 火ノ火キサコ小䋨

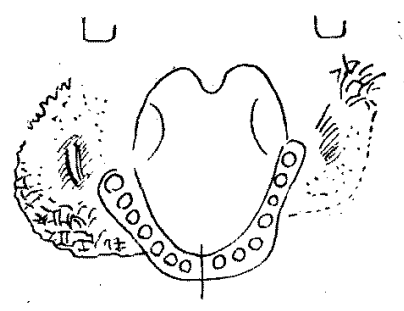
渻キ有スル碳疹ア

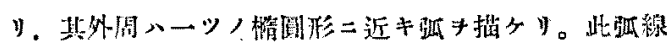

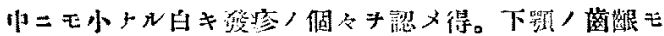

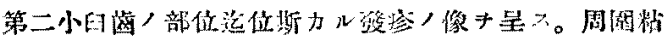

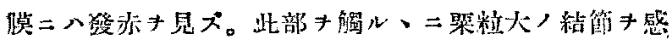

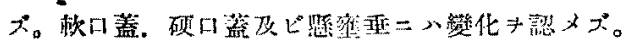

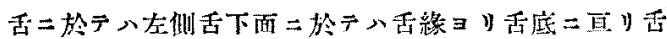

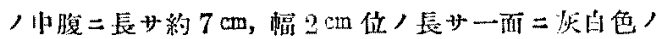

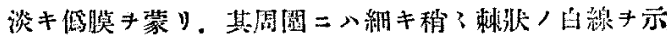

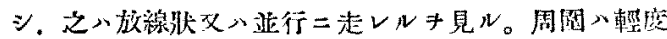

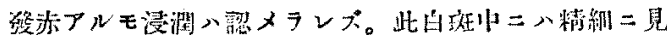

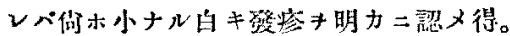

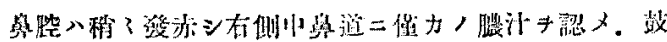
膜入雨侧共二暧度洞濁

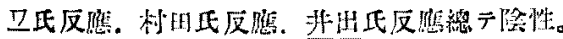

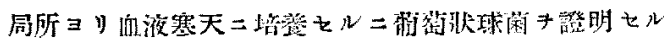
‘。

蓄牙>状管八次圖/如シ。

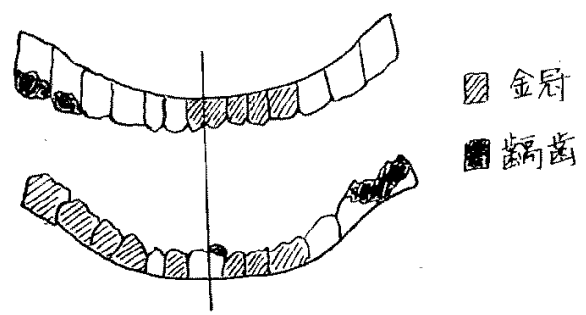

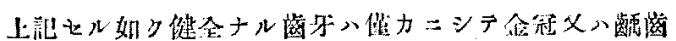

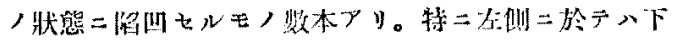

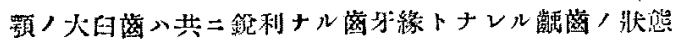

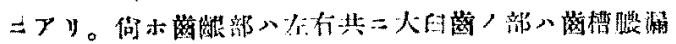

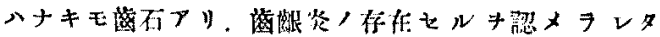

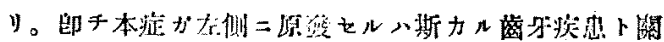
俰ソルモノト思ハル。

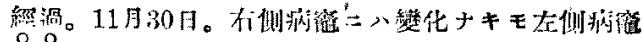
二於公八秒、譃心为兄。 第二大自葍，後部二於

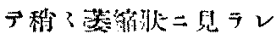
タル部二發疹而斗生三

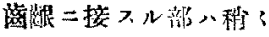

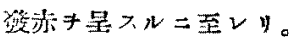

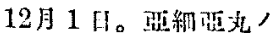
丙腿 1 日 6 粘及「侨

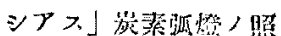
射战分行入。

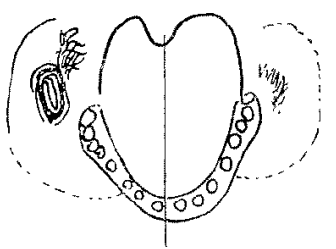

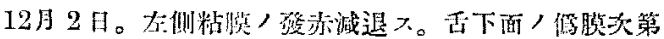

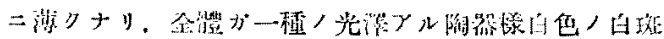

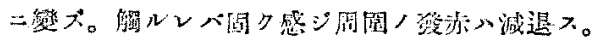

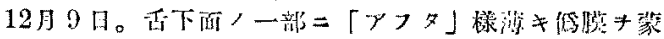
ル潢處キ生ブ。

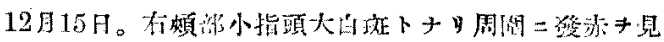

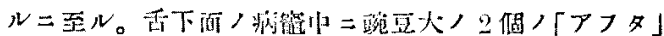

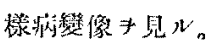

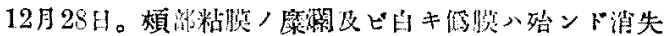

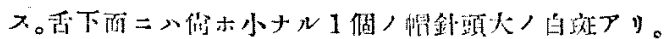

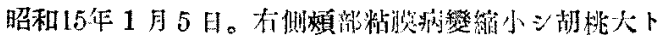

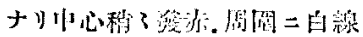

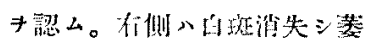

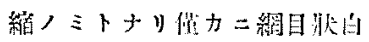
線斗胃ルノミ。苦八小心部二

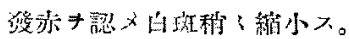

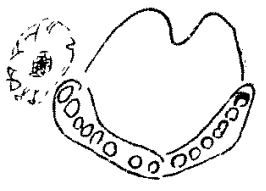

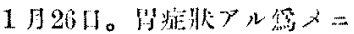

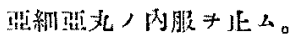
证吪酸人總量 $0.028 \mathrm{~g}$ トナル。

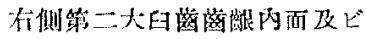

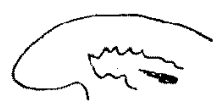

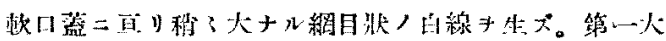

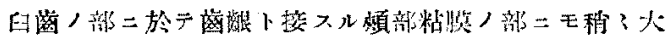

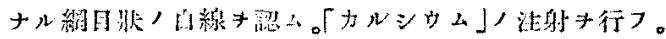

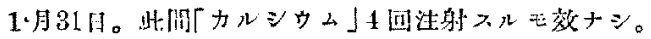

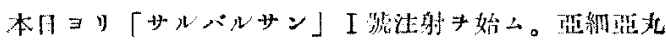

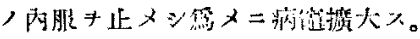

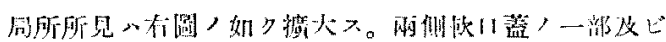


$47-178$

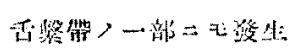

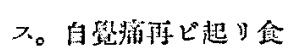

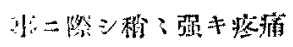
チ都フ。本月ヨy「サ ヘベルサン」I躒/注

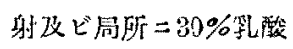
, 整枋斗行入。

2 月 3 日。本Hヨ日本

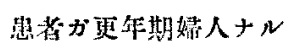

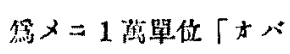
ホルたン」，注射斗始 4.

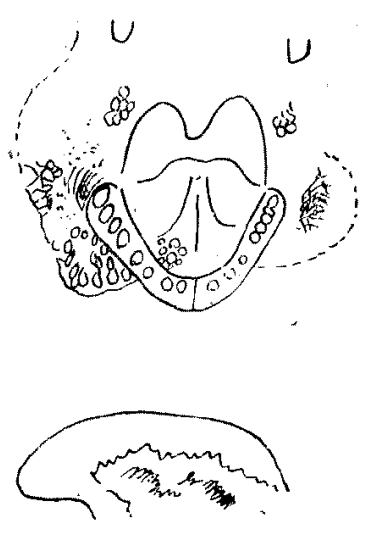

\section{III. 考}

1.文缺人概貉。

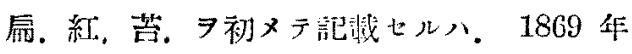

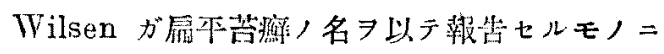
テ. 其後 Kappusi =依り紶色，2字习加へ尖 圭紅色落淮卜俳穛セラレルニ至レリ。其後Hatchinson (1881). Neumann (1882). Crocker (1882). Puslow (1881). Unna (1882). Tauten (1883). Bender (1887). Herxheimer (1889). Kaposi (1899). Truutmann (1909). Schäffer (1907). Joseph (1909). Riecke (1912). Kraus(1914). Mickliz(1922). Kies (1921). Porkorny (1923). 其他多斯，報告了

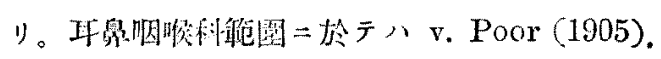
Hutter(1911). Kien(1910). Fliasherg(1913). Fein (1914). A. Bruck (1914). Hislinger (1925). Marschick (1925). Heiner (1921)

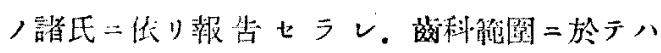
Maladek-Ivau (1937). Minder (1931). Broeqr(1919). Liuerthal(1937). Seider (1936). Willinger (1924) 等, 婤告アり。

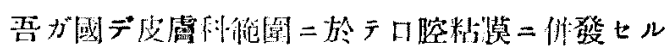

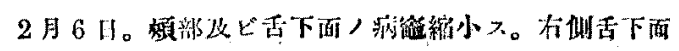

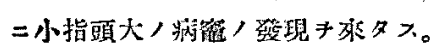

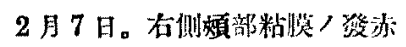

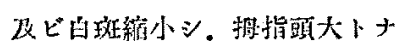

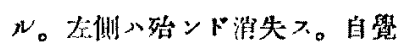
痛ナシ。

2 月 21 月。此间「サルバルサン」I很士回泩射ス。 「ナバホルモン」10回。局所所見ハ極メテ縮小シ右揑

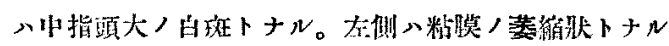

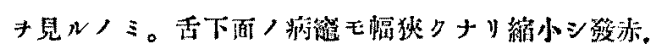

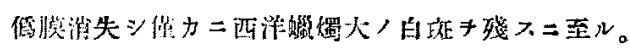

\section{案}

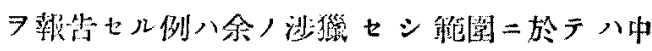
野 (1925)，四代(1928)，检垣(1929)。土肥章司 (1929)，報告アリ。土肥／例八屚。紅。些.中稀十

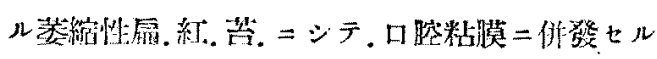

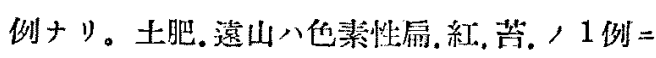

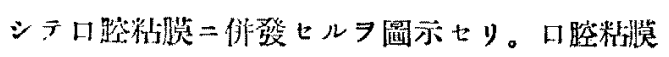
二墢生セルラ報告七ルモノトシテハ遠䐆アリ。

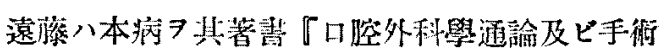

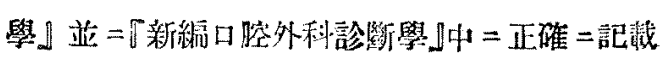
シ. 且ッ其煩部粘膜，四

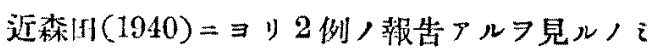

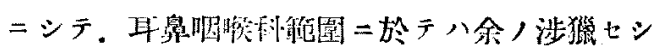
範圆 =於テハ米ダ啹告

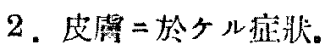

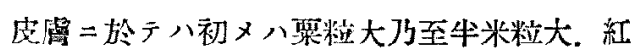

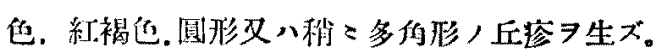
嚾カ二皮膚面上二隆起シ裴面屚平デ中央二八多

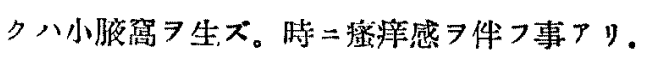

3。粘膜=於ヶ儿拉收。

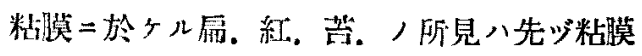

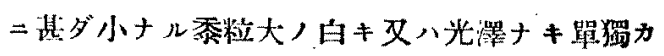




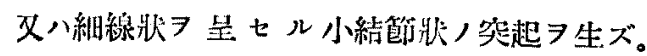
此結笁八透こ八集合シテ群ヨナスコトアリ。此 紨線八其中二小結䈱 7 含 $\mathrm{i}$ 互二交叉シ大小不同 人網目爿

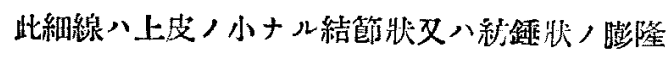
肥厚ョリ成ルモノナリ。此小結第が秒 群ヨナシテ生ジタルトキ八其外側二ハ弓跃刃八 榙阅形ノ瞢ノ形ニテ細線が現ハル、コト多シ。 Hallopea 八此全體，病而，感ジラ「ォブラー

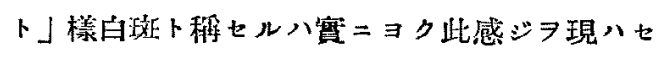
ルモノト思ハル。此病潖八沃第二大トナリ偭部 粘膜二稍 こ大ナル白斑ヨ形成スルニ至ル。此大 キナ䊑こ古クナレル白斑二於テモ精查スル＝僅

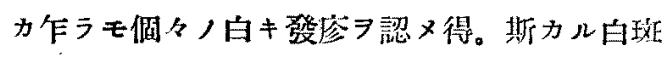

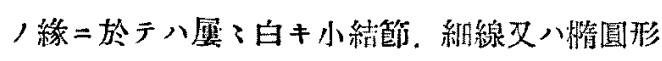

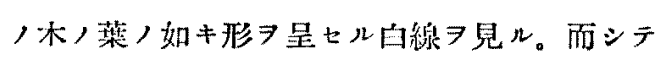
此弧 7 呈七ル白線中二备 $マ$ 小絬節 $尹$ 認又得ル モノナリ。

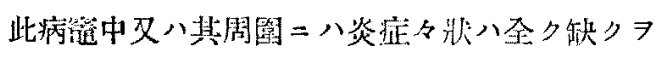

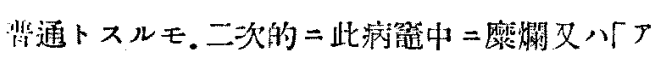
フタ」ヨ生ズルコトアリ。

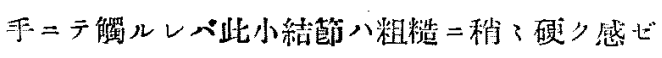
ラル。此感ジ八如何二結節ガ小ナット踓モ感ビ ラル、モノナリ。最初ノ發疹八常二平等/白キ

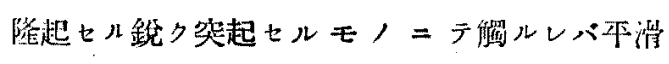

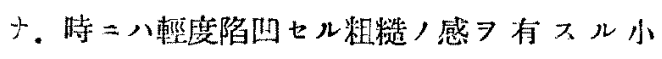
絔篩デ. 䦌圍 =八全ク炎聇症狀ナシ。

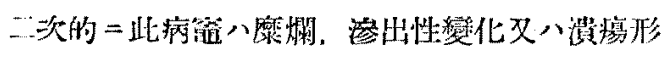
成习是スルコトアルモ。.之八本痘,特辰ナラズ 二次的，變化ナリ。

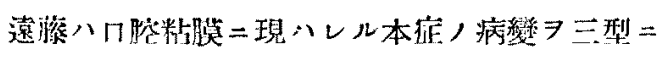
分類七リ。刉千。

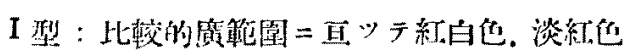

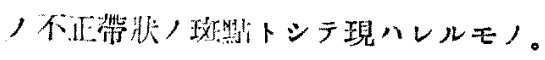

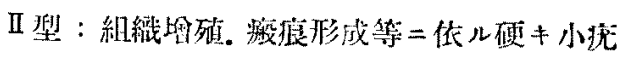
状顆粒文八执照占 。

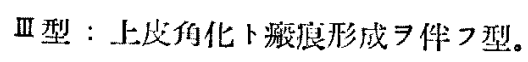

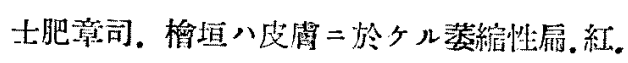

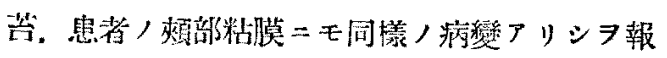

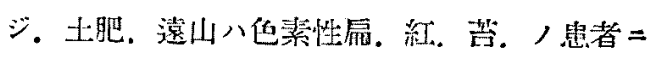
於テ口腔又八口局粘膜=外皮卜同漾, 喑紫色， 色班アリテ少ンク浸潤アリシ例习疑ゼルモ。を 等ノモノ八放。紅. 苦.中二於テモ甚ダ稀レナル 例ニシテ貴重ナル報告例ナリ。斯カル報告例ヨ

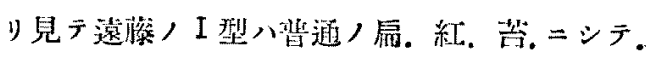

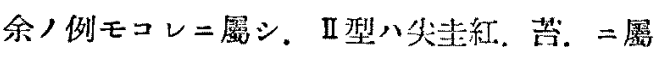
シ. II 型八土肥. 檜垣ノ報ゼル萎縮性傾问，强

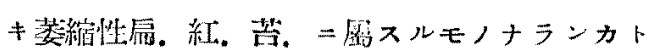
思ハル。

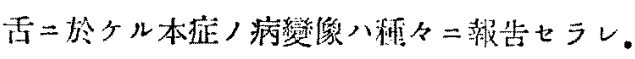

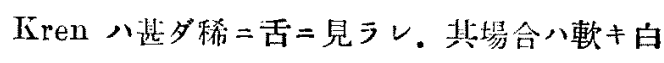

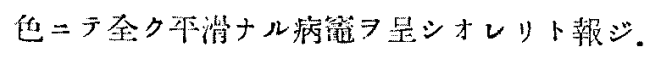

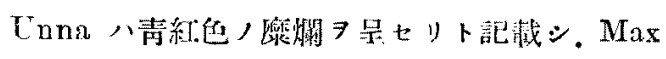

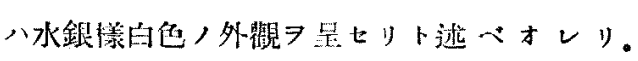
Schäffer, Trautmann，舌卜面=或: 兒ラレ此

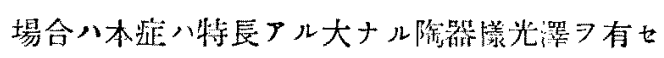
ル畺白キ白斑トシテ現ハルト記诚ス。余ノ例モ 煩部粘膜二於テ八前述七シ如網目䩒八白キ細

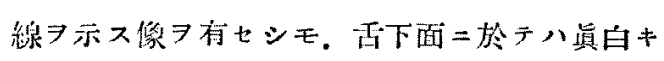
Schäffer, T'rautmann, 述ベシ如陶器揞光

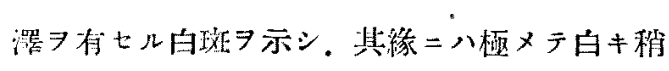
こ本行二走レル白線ノ現ハレタルタ見タリ。煩

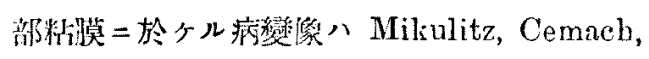

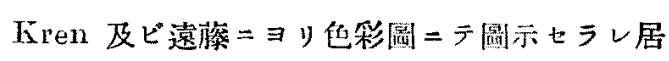
ルモ。舌二發生七ル本淀，泪习示七ルハ外國二 
於于唯一例ソルノでリ。幸七二食ノ症例二於

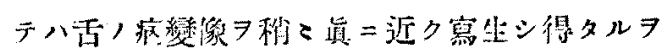
以テ顿部粘茨，圆卜共二附圖トシテショ献ズル 次第ナリ。

結局本症ノ病變像トシラ特長ヅタラレル䍜八限

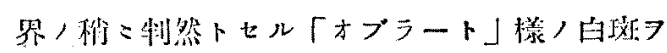

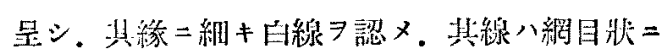

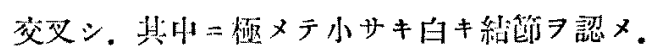
二次的變化 $尹$ 俳ハザル初期二於テ八炎症々状 缺り事，又之二触ルレバ㑑タ，小結简トシテ感 ジ得ル事ガ主ナル斯ナリ。

自覺症收トシテ八一船二背ダ嚾小二テ。初期二

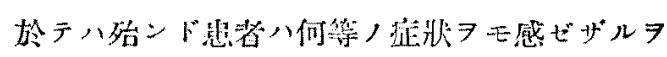

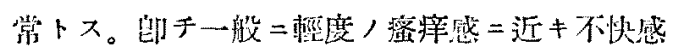
Х八粘膜面ノ粗粃感 7 訴フル二過ギズ。Joseph

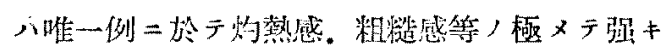

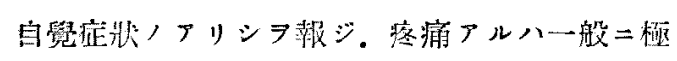
メ゙テ稀ナリト記载セり。Mikulitz モ一般ニハ 自學痛ナキヨ常トスルモ。舌二本庭习發生七儿

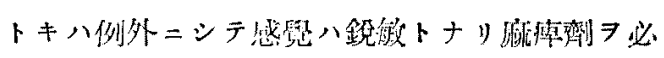
要卜スル事アリト云フ。Riecke八昫熱感特二

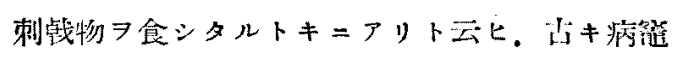

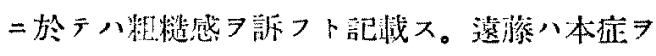

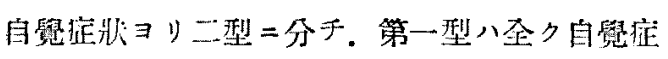

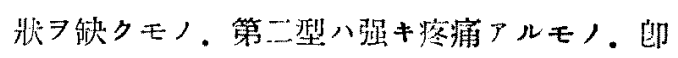

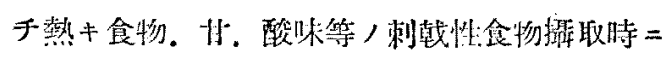
疼痛アルモ，、三型二分ナオレリ。余，例モ望

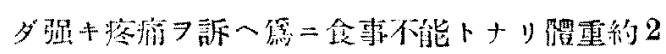

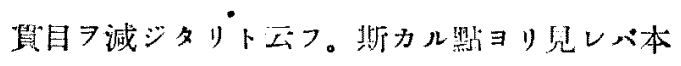

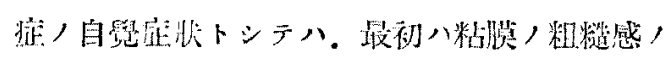

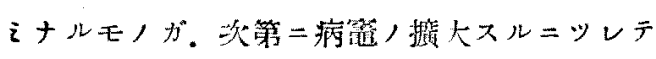

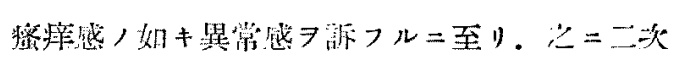

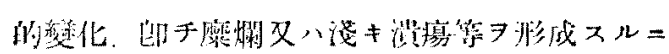

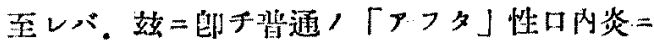

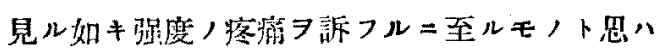
ル.

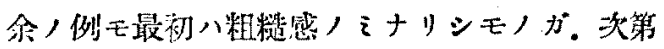

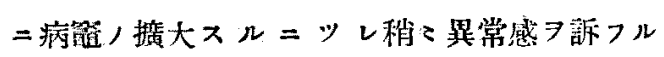
二及ビ. 本症發生以承約釉:年後二至り食物攝取 時强烈ナル疼痛习訴フルニ至り。初メテ醫治习 求ムルニ至レルモノナリ。常外來フ訪レシ際，

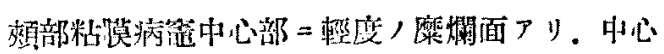

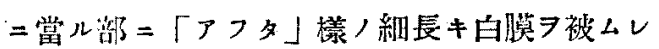

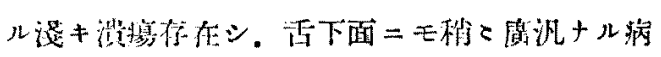

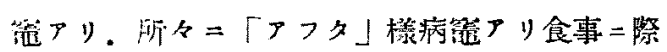

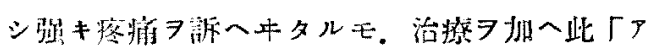

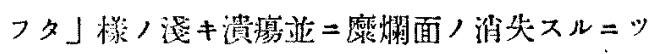

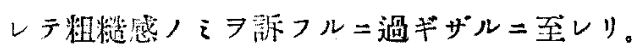

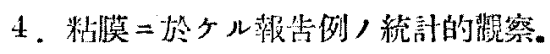

(表 I, II III)

5. 病原 的侖。

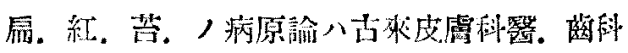
醫其他ノ學学二依りアラュル方面ヨり椧ジラレ オルモ米ダ不朋二屬スルモノナリ。

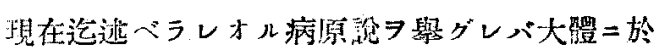

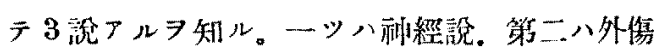

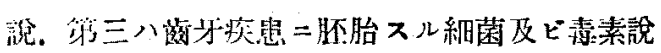
ナリ。神經障碍說ヨ主張スルハWilliger, Seider, Maldeck, Hayes, Brocq, Darien, $T ル$ ᄀ

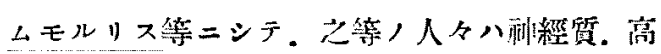

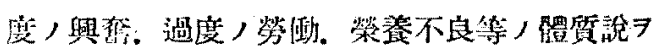
梳キ. Minden, Liebertbal, Miller 等八处稘說

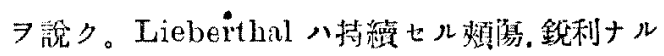

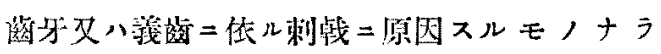
ント蓄フ。第三，路牙疾㭧=胚胎スル細菌及ビ

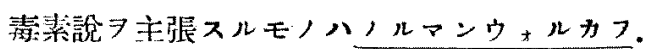




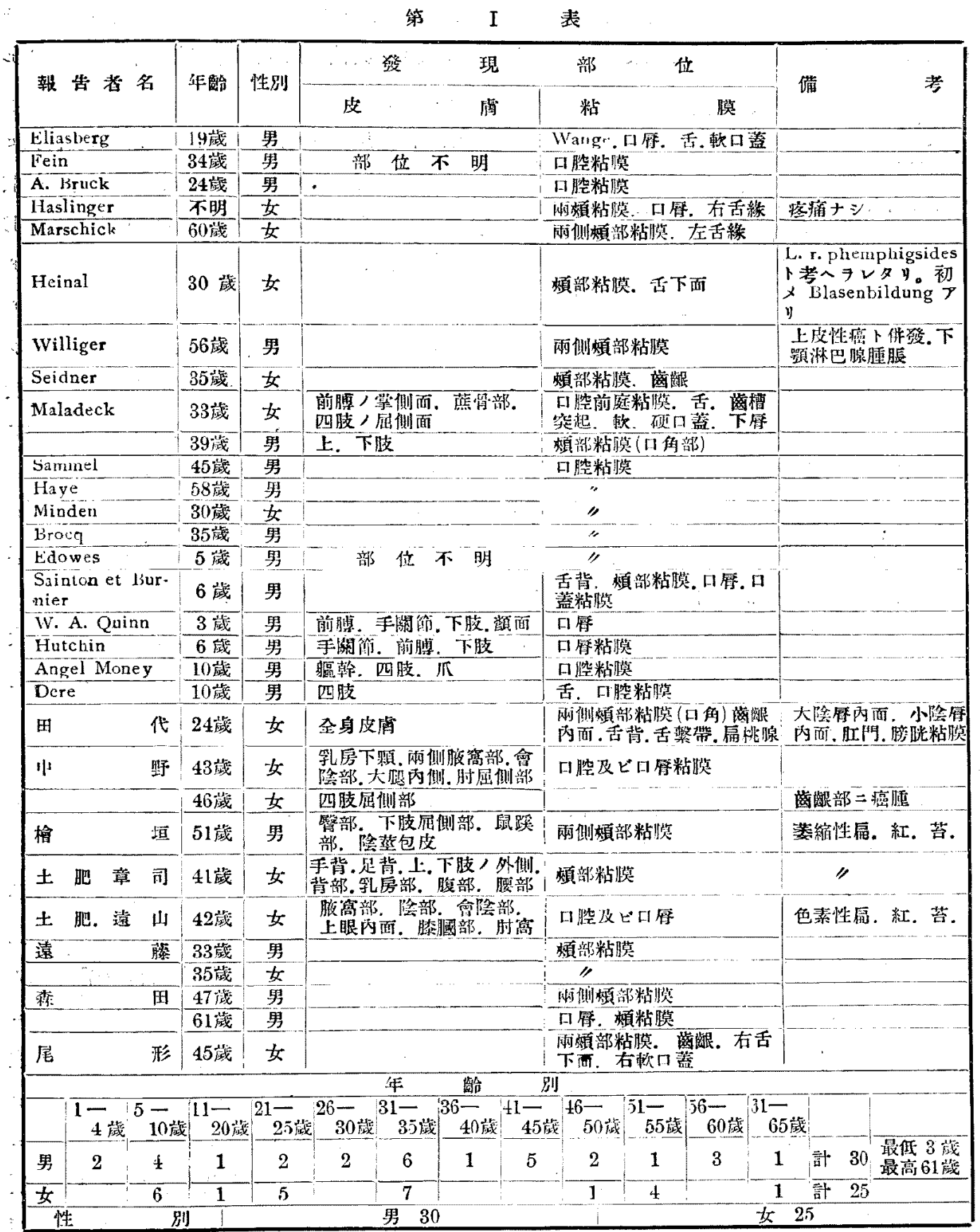

マオルダィス、モンドメリー, Chippmann 等 7リ。Chippmann 八利經系統モ亦本应 7 巷起 スル上袺助的一因形成スべキ, 認メ得ラル

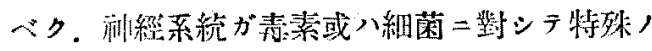
組織結合性 $\exists$ 有スルカ，或八過勞心痛其他，精

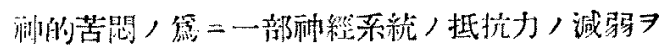




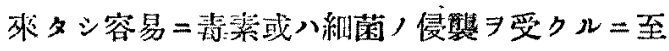
ルノ絬果ナルベシト云つモ。之ハ未ダーツ/假

\section{第 II 表}

最モ多ク見ヨレタル年路及ビ性别

\begin{tabular}{|c|c|c|c|c|c|}
\hline \multirow{2}{*}{ 報告者名 } & 年 & 粚合 & \multirow{2}{*}{ 淀例数 } & \multicolumn{2}{|c|}{ 性 别 } \\
\hline & 最低 & 最高 & & 男 & 女 \\
\hline Kaposi & \multicolumn{2}{|c|}{$10-40$ 鼔 } & & & \\
\hline Little & \multicolumn{2}{|c|}{$\begin{array}{l}35-55 \text { 筬 } \\
(4-81 \text { 鯩 }\end{array}$} & 270 & & \\
\hline Culner & \multicolumn{2}{|c|}{ 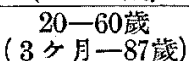 } & $\begin{array}{r}148 \\
(82 \%)\end{array}$ & 82 & 66 \\
\hline Chippman & \multicolumn{2}{|c|}{$30-45$ 旅 } & 8 & 4 & 4 \\
\hline & \multicolumn{2}{|c|}{$21-25$ 政 } & 13 & $\mathrm{L1}$ & 2 \\
\hline & \multicolumn{2}{|c|}{$20-40$ 濊 } & & 52 & 8 \\
\hline Riecke & \multicolumn{2}{|c|}{$20-50$ 萜 } & & & \\
\hline $\begin{array}{l}\text { 尼形 (口腃 } \\
=\text { =琴 ンレタ } \\
\text { 例) }\end{array}$ & \multicolumn{2}{|c|}{$\begin{array}{c}20-50 \text { 藏 } \\
(3-61 \text { 成 })\end{array}$} & 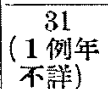 & 18 & 13 \\
\hline
\end{tabular}

定二過ギズト云フ。Chippmann 八自己ノ經驗

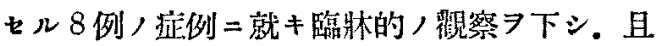

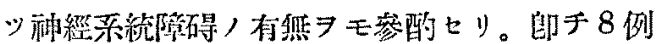

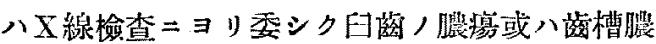

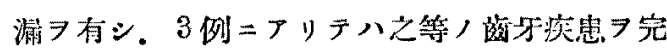
全二治療ノ結果夫し迄各種ノ治療知效セザリシ 本病八何レモ拭フガ如ク治愈二赴キ。3例八落 科的手迴

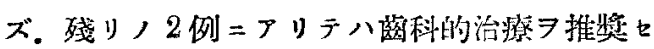
ルニモ拘ラズ再柬七ザリシタタ二其結果不明ナ リシト云フ。Chippmann ハ 8 例中女子 4 例二 アリテハ，2人八䣓經質ト程シ得れ部類二編人 スルタ得タリト云フ。侗木 8 例/年䍉八前逃七

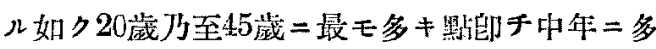

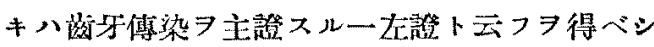

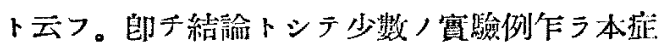

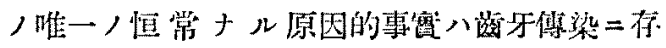

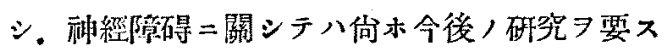
ト云フ。

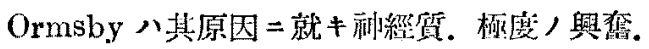

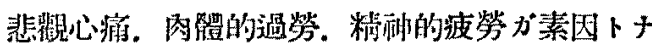
リ犬十鼠其他二依ル瀷浪，咬聁等ガ誘因トナル ト云フ。

余,例 3 見ル =本例八 4 歲ノ女子

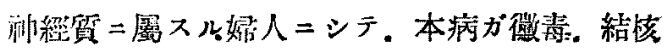

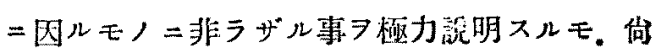

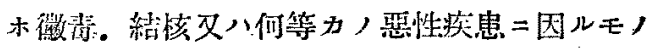
ニ非ラザルカト云フ事ア再三再四反問シタル

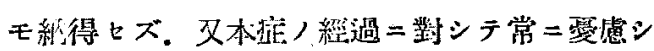
整時治療 本外棑习訪几㥞ス、メタルモ，其瑟化スル事习 恐レ完全二治丞スル迄治療ヨ受ケタシト希望セ

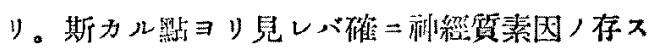

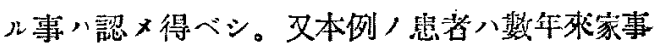
二追ハレ睡眠時間等モ短ク阁篮的二過勞ノアリ

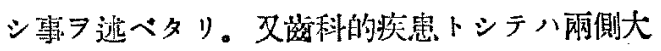

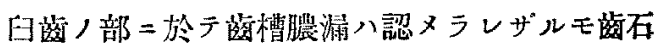

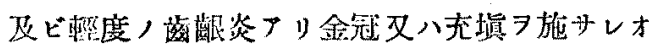
レリ。

斯クノ如ク本症二對ス儿病因二就テハ份木種々 不明，默侈》今後，研究二待ッコト多キ二屬 ルモノト云ハザルヨ得ズ。余，症例二於テモ神

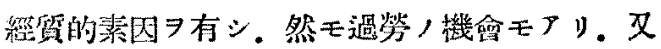

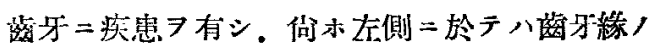

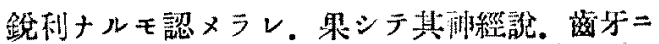
ヨル外傷説, 又八細菌表素說等，何レノ說 $=$ 左

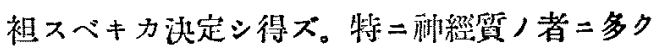

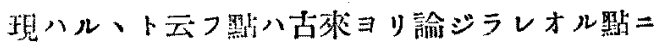

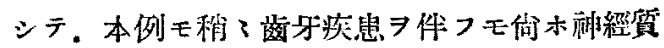

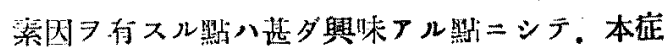

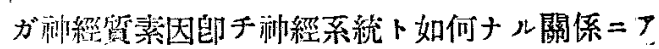
ルモノナルカハ倘木今後老分ナル研労的餘地 7 残スモ，ト荟へラル。 
6. 年路及性別。

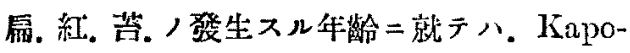
si 八10 歲乃至40歲. Little 八 270 侧中最低 4 歲. 最高 81 歲ニシテ.最モ多キN35歲乃至55歲ナ リト云フ。Calver ハ14E例中 3 ケ月乃至 87 歲，

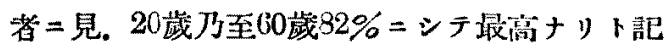
シ. Chippmann ハ 8 例 7 朝ジ。年㻌八30嵅以 上45蔵ト報ジ，吾ガ國二捻テ八菊池八12例中。

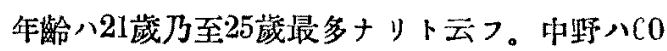
侧，報告中大多数八20歲方至40歳ナリト云フ。 食 集メシ口腙粘膜二作發又、特發的二發生七

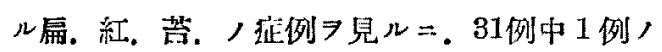
作业不詳ノモノフ除キ30例中最モ多ク見ラレル 八31歲ヨリ35藏二至ルモ) =テ 6 例，(41歲 $J^{\prime}$

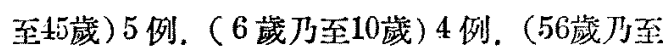
60 歲) 3 例。（46歳乃至50藏. 21 歲乃至 25 歲. 26

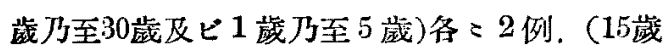
乃至20歲。36歳乃至40歲。51战乃至万5藏。61藏 乃至 65 歲)各: 1 例 リリ。 710 年代 $=$ 分類 レバ ( 1 歲多至10歲) 6 例，(10藏乃至20葴) 1 侧. (21藏乃至 30歲) 5 例。(31歲乃至 40 歲) 7 例. (41藏乃至50歲) 7 例. (51藏》至60歳) 4 例. (6)

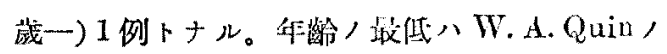

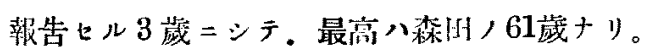

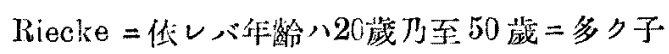
供ニ八少シト云フ. Kiess 八小兒二發生七ル厥. 紅，苔。189 例，報告例 7 集又。繶計的二推察 七ル八興咑アル所ニシテ。子供ニハ少シト云つ モ. 斯かル所ラ見ルト子供二モ時折見ラレルモ

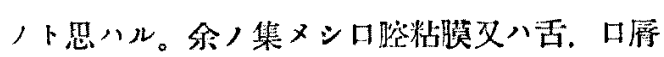
$=$ 關係厂ル症例 30 例二於テモ (20歳乃至50歲)

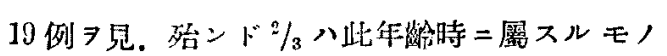

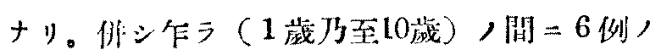

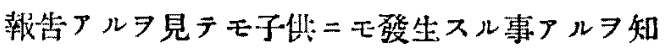
$r$.

性別トシテハー般二男子二多ク女子=少シトサ レ. Riecke $=\Xi$ レバ男女ノ比ハ $3: 1$ ト記サ v. Calker 八148例中男8 8 例，女子 60 例。菊池 八13例中四子11例，女子 2 例。中野八60例中男 52例，女子 8 例卜唘シ。余，集メシ症例 $=$ 於テ モ男女ノ比八 $18: 13=$ シテ約 $3: 2$ ，比卜ナリ 男子二稍く多キ結果トナル。

7. 好發部位。

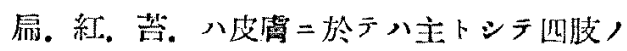

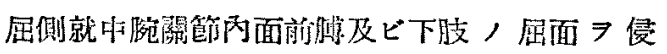
シ.次二胸. 涘部及ビ側嗄部並二背部=來儿事多

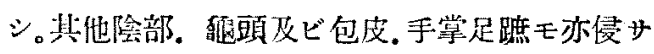
ル。晹面八稀レナリ。

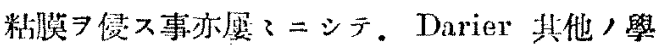
者=ヨリ約坐數 $50 \%$ 刃ハ夫レ以上，率=及ブ ト云フ。叉 Darier 及ビ Thibierge 八粘脵發 疹八皮覤發疹二先キ立ツテ發生スル事アルラ注 意七り。本症八紸膜ニ八發生七ズト云フ。 粘膜 =發生スル時二於テモ口貯䉼膜=發生、ル 事最モ多っ. 特二煩部粘膜二於テロ角部郎千第

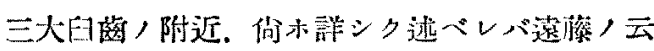

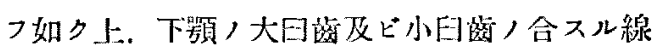

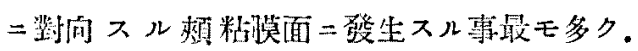

Trautmann 及ビ Jadassohn =依レベ数膜=

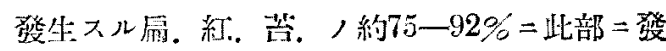
生スルモ，ト云つ。煩部粘膜，前面二發生スル

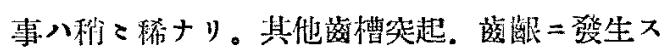
ル事〉リ。舌モ時々侵州儿。舌二筑生不几場合 二八舌北.舌称. 及ど舌下面二發生シ. Schaffer,

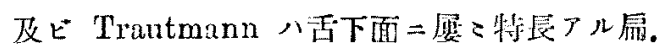

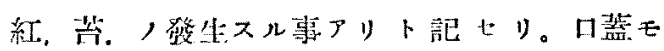




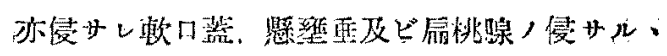
事八的 1ー2吕二見ラル、ト云7。下辟三見

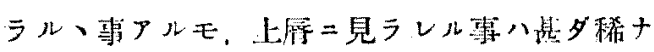
1)。

Rona 及ビ Bruck，八咽頭，後哭=昌ラレタル

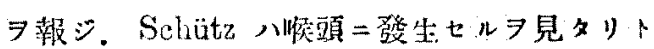

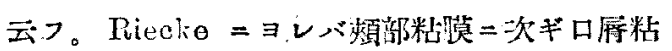

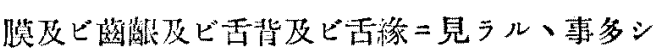
ト云フ。

口然粘膜以外，報告八稀レンシテ。肛門粘膜= 發生七ル尹報シタルハMax. Herxheimer 及ビ Stobwasser アリ。膀脱粘慔二就テハ Issac II, Zerpowitz，Heymann，報告〉リ。陰阳及ビ 控二就テハ Yolland，報告アリ。

余，集メシ症例二於テ煩部跕膜二見ラレタル例

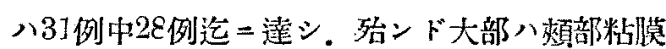
二發生シ. 舌二見ラレタルモノ8例. 口㕌=見

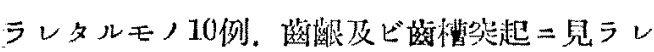
タルモノ 5 例。口蓄/記载厂ルモ，5例中㜞口

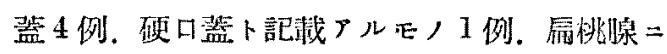
見ラレタルモ/ 1例厂リ。他ノ粘呺莫二見ラレタ ル報告トシテハ中野ノ報告例二於テ大㓌曆及ビ

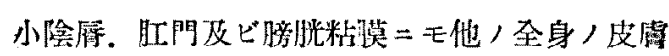
疾患及ビ口貯粘膜. 舌. 屁桃腺等卜同時 $=$ 發生 セルラ報告シオレリ。此中野例入全身，艾溜度

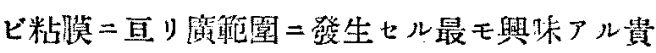
重ナルー例ト云フヨ得ベシ。

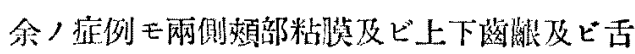
下面. 軟口蓋ノ一部=运胃ラレタル一例 ニシテ 發現部位的ニモ興味フルモ, ト考へラル。

\section{8. 發生率。}

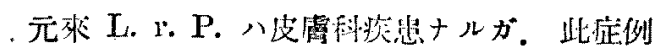
，皮膚科然格 7 訪レル統㖕 7 見ル二。昭和 9 年
=山本ガ山形门立病院 10 年間ノ統到 =依レハ 7935 人中 4 人ニシテ0.05\%，率トナル：市國大

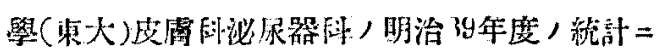

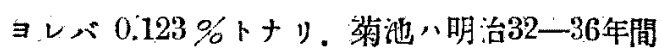

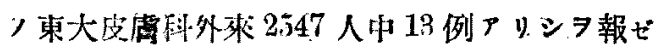
リ。粘膜二特=口路粘膜=脌發スル事八1880年 來既二知ラレ.Wilsen，少50 例/本定患者中 3 例. Rona $八 18$ 例岳 6 例. Körpner 八 52 例中 7 例. Herxheimer 八127 例中 98 例 7 報告入。 Heuss $\wedge 40 \%$. Gaulier $\cong 2 \%$. Darier $\wedge 50 \%$ ト程シ。 Kiess 八小兒二見ラレタル・L. r. P. 患者89例，症例 7 集又步中 9 例二粘膜=侻發七 ルラ報䇢シ。其中舌及ビ口貯粘膜二發生七ルモ ，6例アリタリト報告ス。

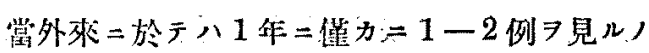
$i=シ$. 森时ニヨレハ「アソカ」病院菻科外 柬二於テハ1年二少クトモ3例以上ヨ馀几ト云 フ。斯かル所 シタル場合八耳鼻咽喉科习訪ル、ヨリモ贯科 訪レル率ノ方が多キ栐二思八ル。特二最近㰧米 茼科醫界二於テハ本应が時トシテ大ナル疼痛。 不快感 7 伴比食事不能=陷ル事厂ルタメト。

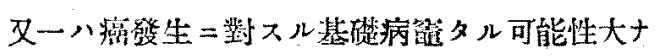
ルモ,トシテ最近十数年來其報告例鲳加シ。 Williger (1924), Prinz, Seider(1936) Э始トシ

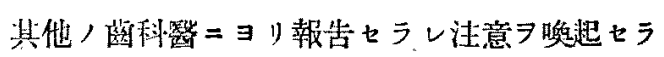
レタリ。

9 、縒過及ビ涭後。

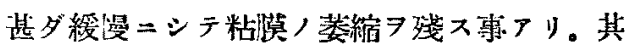
縃過八柾メラ徐々二長期二亘り數年=及ブ事厂 リ。

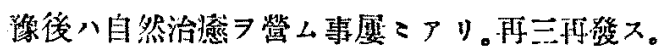

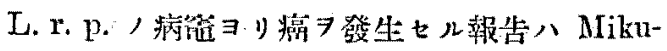


ritz u. Kümme], Dettnann, Williger 收ビ

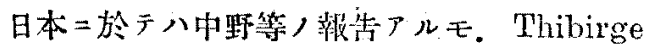
八斯カル Schleimhant，病變ヨリ八痁八繁生

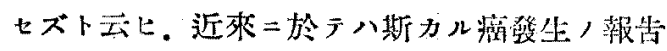
ニ接スル事ハナシ。

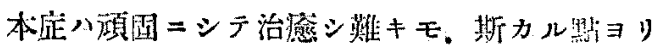
見テ本迹，激後八比較的良キモ，卜思八ル。

10. 合 併症。

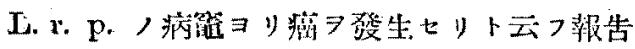
八 Mizulifz, Kümmel, Bettmanu u. Williger ニヨリ報告七ラレ學界/注目习悉キタルモノ= シテ.本邦二於テ八中野，報告例二接ス。Miku-

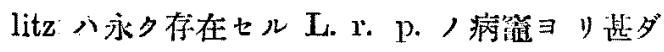
瑟性ノ舌癌，發生セルラ゙報ジ。Bettmannモ同 棣〉一例報ゼり。Williger 八1924年“Lichen ruhen planus u. Karzinom"ナル報告 $=$ 於 テ56 歲男子，兩側頓部粘膜 =發生七几 L. r. p.

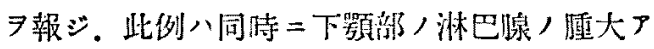

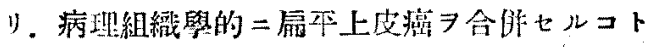
7 記载义. Williger 八2? 例中 2例, Karzinom アリタル 派告シ L.r. p. 八比較的良性，资患

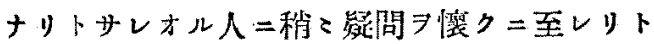
報ズ。本邦=於于八.中野八大正 3 年 46 藏女

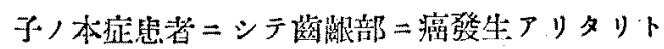

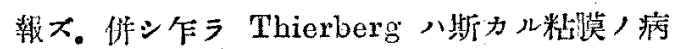

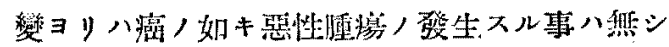
卜思考七ラルト云フ。余モ亦本症，臨牀的所見

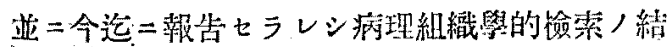
果ヨリ綜合シテ，本症が恶性腫疼二轉ズル倾向

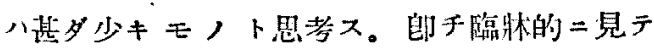

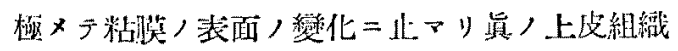

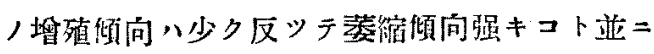

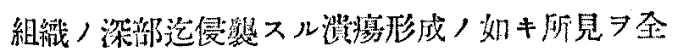

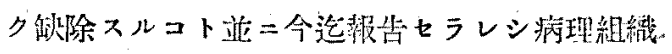

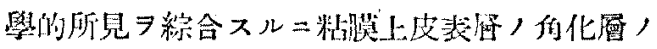

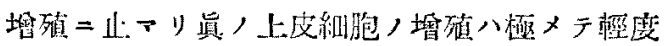

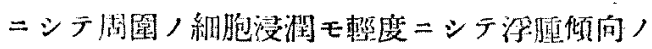
强キ點ヨリ斯カル病變組織部ガ上皮細胞，異型

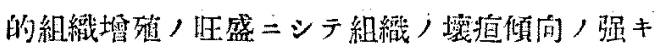
惡性腫济タル癌等二繼化シテ行クト云フ事八臨

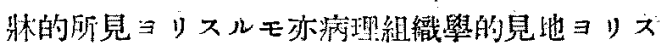

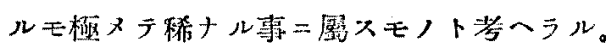

\section{1. 病理。}

本症，病理組織學的檢索 7 行へル赫告ハ Lupasiewicz, Franz v. Poor (1905), Vorner, Riecke, Trautmann, Dulia Ferera Hejes

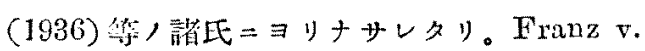
Poor 八190j年 "Zur Anatonie der Schleimbautaffektionen bei Lichen Planus (Wilseu)" ナル啹告二於テ詳述七り。Heyes 1936 年二

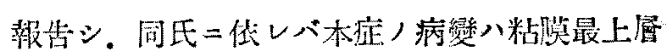

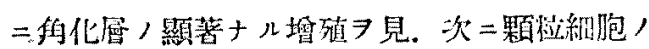

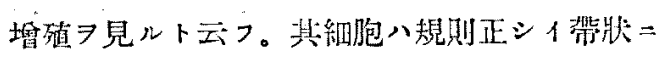
限定サレテ血管八摭张シ浸潤七儿緗胞八主トシ テ淋巴球ナリト云フ。

本症，病理組織學的所見八乳頍部並二乳頚下部 二於テ主トシテ單核白血球。多數白血球及ビ 「ブラズマ」細胞ヨリ成ル浸淜アリ。血管”僅カ

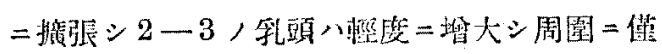

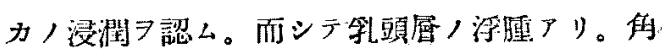
化㕍八溥クナルカ又八肥厚ス。而シテ時折「ケ ラトヒアリン」居ニヨリ蔽ハル。臨归的二八侣力 ，例二於テ上皮表篔，萻シキ塽小ナルモ， 及

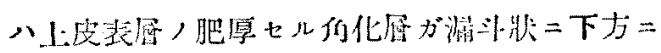
沈大セルヨ見ル事が「ル。時二, Josephsche

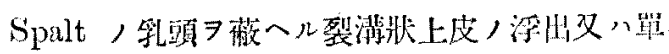


二一部二於テハ“Josephsche Spalt 夫レ自身 ガ時折存在スル，見ル事アリト云フ。

12. 撚法,

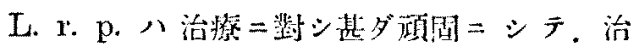
瘾セシんル事困醮ナル疾㭧ナリ。先ヅ第一=淟 ゲラレルベキモノ八吪素緛，長期=亘ル內服及 ビ皮下注射ニシテ.「サルバルサン」/靜脈洤射 モ或程度迫八有效ナルモ全治セシメル事八不可

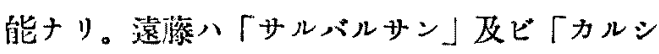

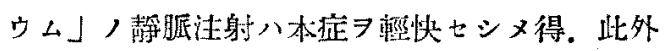

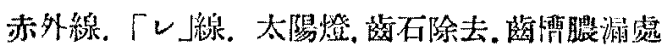
置习行フモ自覺的苦痛又八發赤 ズト云フ。

局所二ハ柇品习用ヒザル方が良イトサレオレ リ。Postoma ハ「ペルーパルサム」ヨ墨滴スル

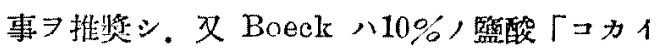

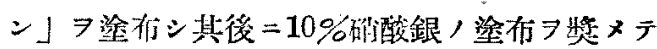
キルガ之八試んべキ事ナラズト照ハル。森四八
$30 \%$ 乳酸，塗住习施行せり。作シ乍ラ局所二简 蝕劑 $尹$ 使用ス儿事八余王亦替成七ズ。

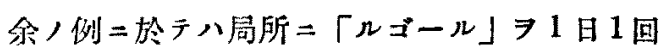

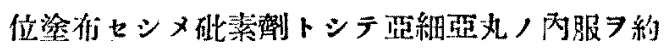

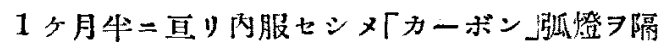

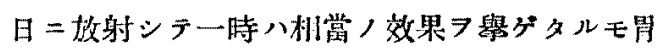
症狀，發現スルニ及ビ 2 ケ月後二至り吪素㓯，

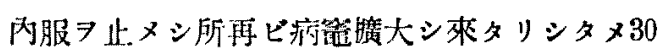
$\%$ 人乳酸塗有トサルバルサン」注射ヨ行七。 份木本例八更年期婦人ナリシフ以テ其们經症狀 フ除去スルタメ「1楞單位オバホルモン」注射 ア行ヒシニ「サルバルサン」I號 4 本。「オバホ

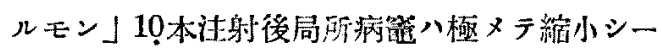

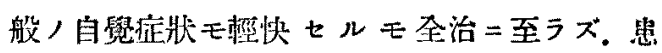
者ノ都合ニョリ一眭治療 リ。即千約 3 ケ月二亘り吪素劑，注射道=內服 及ヒ局所二桬液䇺布习行ヒシモ遂二全治ヒシメ 得ザリキ。

\section{（二）口䏶徽毒二就テ}

\section{I. 緒言}

口然及ビ四頭＝微毒，發現スル事ハ甚ダ㕍 :

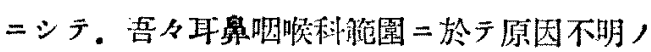
單純大几炎症卜考人得ザル局所所見. 刃八全身 症彇 7 是シ來タリシ患者二接シタル時二八, 肯 カラノ占讜二モ謂ハレル如り微表二非ラザル カト云フ監念习懹ク事八極メテ必要，事卜思八

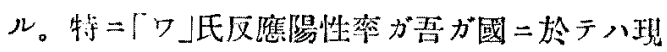
在佾木少中場所二於于䄪 $4 \%$ 。多場所二於テ 八10\%ヨ超へル状態ニアルラ以テ常二徽毒性疾

\section{II. 症}

患者。48茂，男子。初路4月20日。

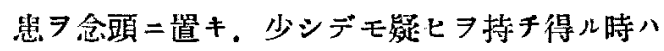

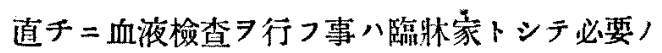
事ト思ハル。

口腔及ビ咽頭ノ精細ナル診查二依りテ全身微毒 7診定スル機會二遭遇シ得ル八比较的屡 了シシ

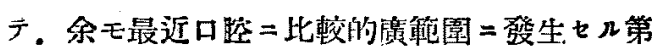
二期徽毒症例二接シタル

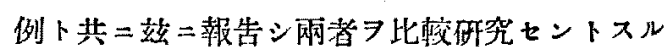
次第ナリ。

\section{例} 家族㻺。特祀スジキ事ナシ。 


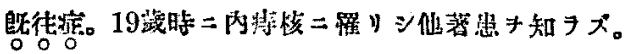

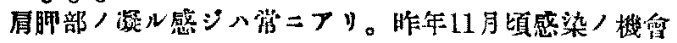

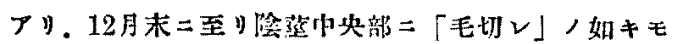

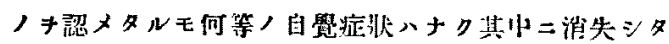
y。

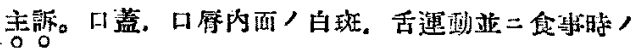

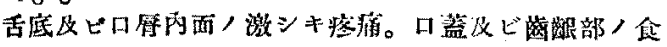

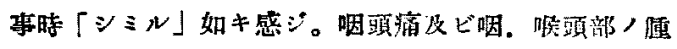

\section{瞹忽。}

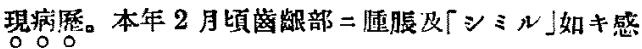

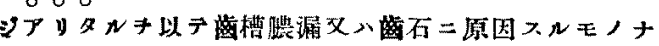

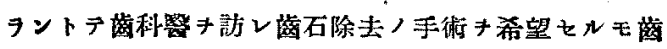

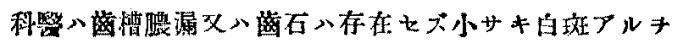

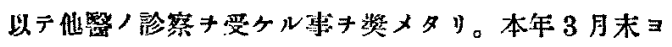

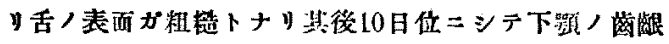
内面二粗精ナル感ジ起入。食事時刺戟物ハシミル。

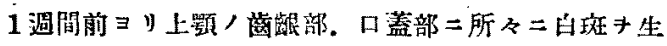
ゼりト。4 日前ヨり固形物ハ疼痛及「シミル」管メ二

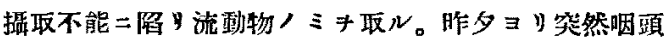

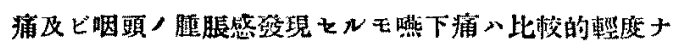
ソ。昨夜入時々矦頭部ノ絞扼感フリ時々呼吸苦シク感

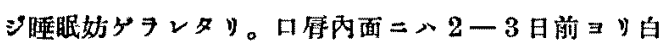
斑キ生ジ本朝二至り上下口原ハ浮脏状二腫大もり。

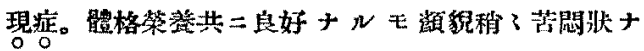

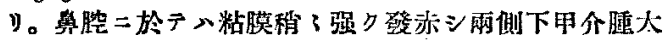

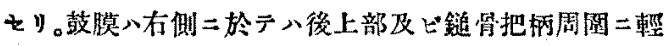

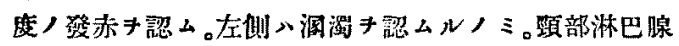
八雨僛共二扸卵大八厓脹アルモ医痛入少シ。咽頚粘膜

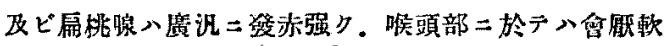

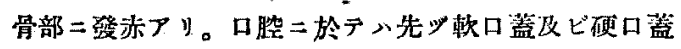

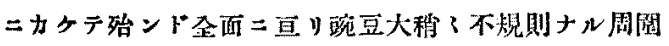

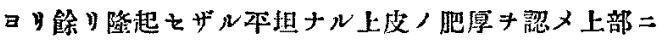

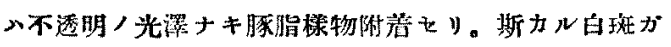

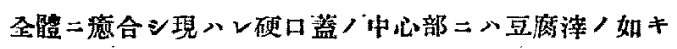

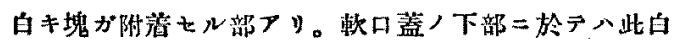

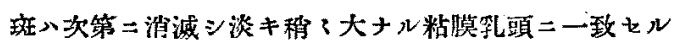

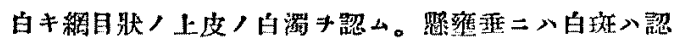

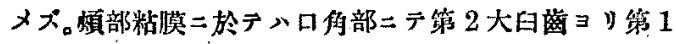

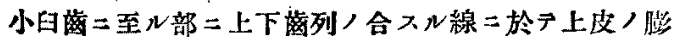

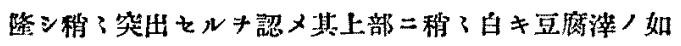
キ不透明八白斑被么N。舌二於テ八舌表面八稍?厚 平黄色ノ舌苔つリ。舌下面二於テハ慗帶ヨり舌粘膜卜

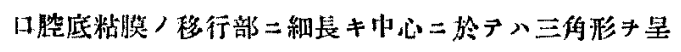

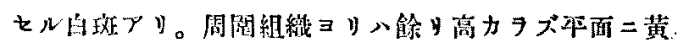

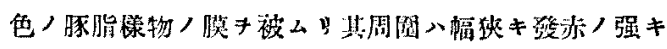

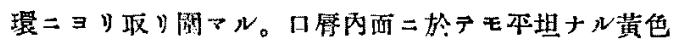

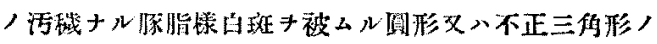

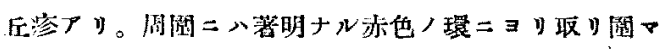

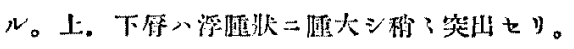
亚出氏反㦄悔等度陽 性. 口氐反照隆性。村 田氏反慜陽性ナリ。 經瀜。4月20日。 㨁チこ「サハバサ ン」I路ノ沙射キナ 洞時二沃度加里 $1.0 \mathrm{~g} \neq$ 投與不。 4 月23日。口篮主 斑稍了綃小メ。煩部 粘膜，白斑玉消失七 》。煩暗二於テ八特

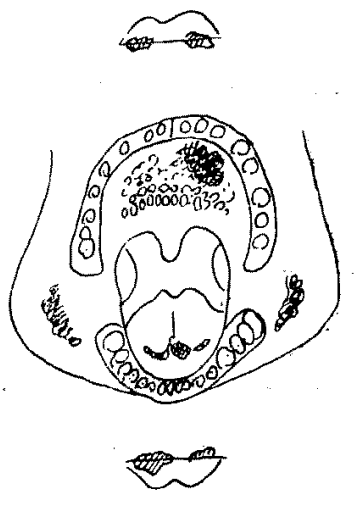

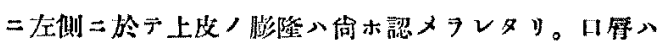
肴ク其浮腄八減退七 ルモ口得表面二 2 3 個八白斑キ生ズ。 4月 24 日。「ギフロ

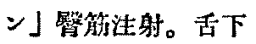

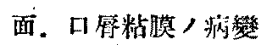
$\sim 10 \%\lceil n ロ-N\rfloor$ 亞鉛二西底领入。 4月25日。蓋二於

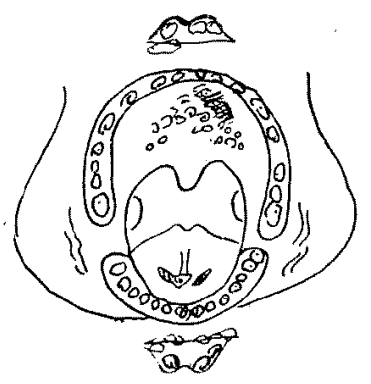

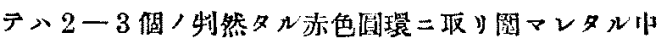

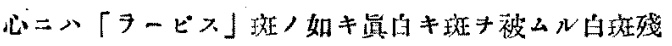

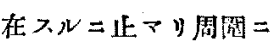
八淡丰器讯+ル上茂” 檞了溷濁七ルキ浔ムル 二過ギプ。听盾/目玟 モ繀小シ数モ減ゼタ。

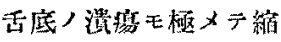
小シ自配痛モ楚ダ娍退 ス。淋巴腺腄脹モ減 退セり。

4月28日。「サルバル

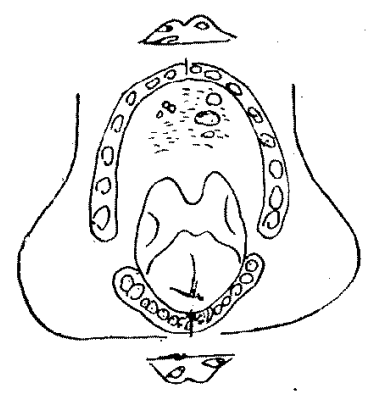

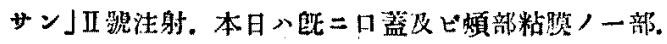



$47-188$

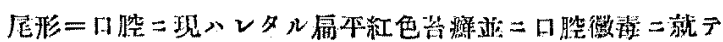

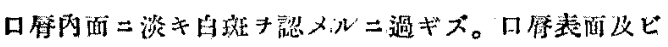

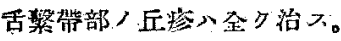

\section{III. 考}

\section{1. 第一期徽素。}

生殖器以外，感染部位トシテハ口貯及ビ咽㩆 ガ第一二舉ケ゚ラル。Gerber =依レバロ腔咽頭 =發生スル倅八 $35-45 \%$ 二洼スト云フ。

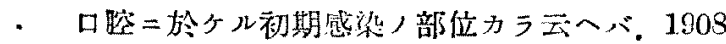
年 Gerber ハ口腔及ビ咽頭微亚，5750例中口 屑ニ見ラレタルモノ2763例 $(48 \%)$ シシテ・ソ ノ部位ハ下几㻺中央部最モ多シト。舌 245 例

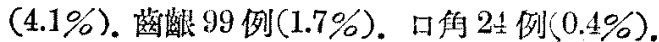
口蓋 14 例 $(0.24 \%)$. 煩部粘膜 6 例 $(0.1 \%)$ 卜報

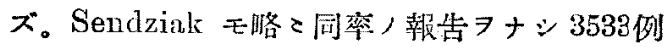
二於于口原 1441 例 $(40.7 \%)$. 舌 205 例 $(5.8 \%)$.

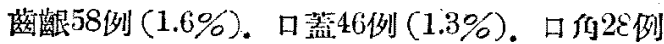
$(0.8 \%)$ ，㚘面部粘膜 19 例 $(0.5 \%)$ 卜派ゼリ。

此部位，第一期得素，感染徑路二八直接卜間接 トアリ。直接感染八接吻，不正ナル交淁，授乳 ニ由ルモノニシテ. 開接感染八微素二テ污染七 ラレタル器具郎于酒杯，笛，茶碗，煙管。菤煌 草等ニ由ルモノナリ。

局所所見トシテ八初メ八指頭大八平盐ナル表皮 利離，贆

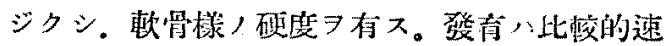

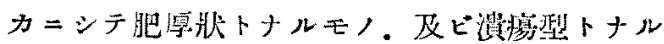

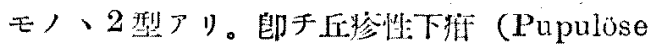
order bypertrophische Schanker) 及ビ㴖瘖 性下掋 (Ulzerose Schankel) えナり。斯ク，

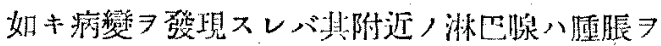

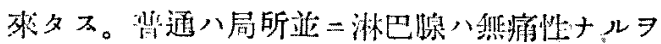
以ラ特長トスル。作シ乍ラ之等局所病變部及ビ

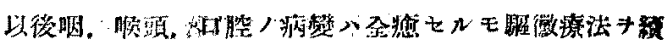
行をり。

\section{案}

淋巴腺二二次的感染，來夕山几場合》疼痛及ヒ

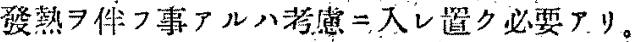
經過トシテ八感染後 $3-4$ 週ニシテ起り自然的 二消退スルモノナリ。血清「ワ」氏反應八通常 感染後 6 週=シテ球ハレルモノナルモHotbmann 八初期硬結 $コ$ 第二期症师，出現迄 76 週 トシ其前牛期ヨ血清反應陰性期トナシ其後牛

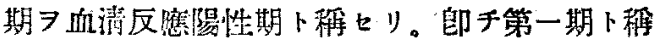
スル時期 二於テ壬㼛二血清「口」氏反應陽性 ナル事厂リ，其陽性率八 $50 \%$ 冈外卜見テ可ナ 甲.

口. 第二期徽毒。

第二期微毒入感染後 $6-8$ 週ニシテ病原體 淋巴脉及ビ血行 $=$ 入ル =因り赸り皮庂卜共=粘 膜師チ口腔。咽頚. 鼻咽腔=發現ス。第二期微毒 ，口然=發生スル秉八皮㲊科舆 Watten 八 60

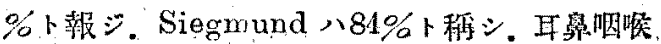
科㗨 Gerber ハ28.6\%ト云フ。

第二期徽毒，口腔粘膜三發現ス的場合八 2 型厂

リ。即チ紅斑 (Erythema) 及ビ丘疹 (Papel) そレナリ。

\section{1. 紅站 (Erythema)}

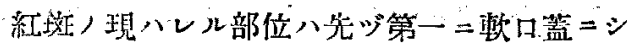

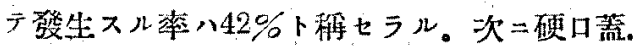

口脣. 植部及ビ舌ノ順トナル。

細斑八先ヅ廁範ナル發亦トシチ現ハレ之八特異 ナル所見ヨ存七ズ、酱通！「アンギーナ」ト！

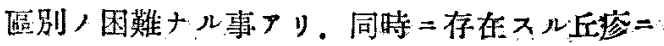

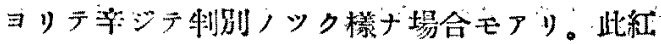


斑が限局性:=來タレル時分稍 ! 特有, 所見引有 *0.5-2cm) 遖德 7 有ス认斑 (Roseola) 又八 線狀トシテ健康粘膜內二拱がル事アリ。

\section{2. 丘疹 (Pupel)}

此中 $=$ 八 Condylona latum, Plaque miqueuse s. Opaline, Stomatitis papulosi 7 含 ムモノデアルガ.之二多ク八肥厚シ膨隆七ル灰 色,上皮ヨリ成り周圍粘膜カラ八餘り判然卜區 别セラレズ。

此丘疹ノ生ズル主ナル部位ハ口愿内面。舌. 次

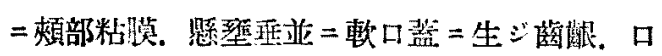
腔底。硬山葢八侵サレル事ハ少シ。

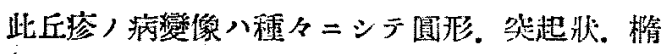
圆形及八細線狀

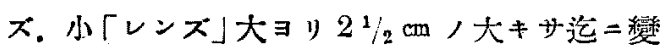
化シ其數モ 1 偑力ラ比較的多数=發生、凡事ア リ。其發現，梯子モ對照的二柬儿事つリ，不規 則ノ事アリ。群ヨナス事アリ，又特二軟口筧二 テ八全塩が集合七ル如キ像

初期二於テハ㱠ンド周園組䋨ヨリ隆起七ズ後二 八苗床形，本坦ナルモノトナル。其色八初八メ 真紅色デアルガ上皮ノ肥厚卜共=黄白色トナリ

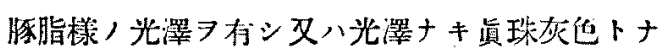
ル。而シテ比丘疹八多少場合槅，㷋人赤色是 ニョリ取り園マル。恰モ「ラーピス」又川确酸

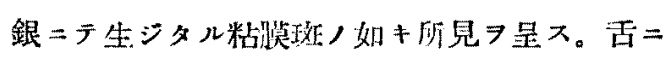
於テハ此丘疹八主トシテ舌尖。舌緣及八舌下面 二發生スル。又屡 、舌底二淋巴組織，肥厚 7 生 ズル事アリ。Riccio，德青ノ場合 $60 \%=$ 斯カル 變化 $尹$ 柬タスト云フ。舌背二於分特長アル

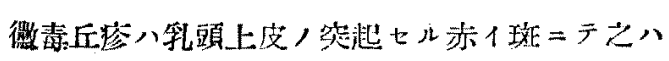
約 Im ヨリ小デ全舌背=見ラル、モノデ. そョ 初メテ記载セルハLieven デ. Siegmund 八
1863 年之 $\Rightarrow$ Psoriasis lingure トシテ埇ジ。

C. Keiserberg 八 laques lisses 卜秘七り。 斯カル丘疹力゙封期が經ツカ又八二次的變化习件

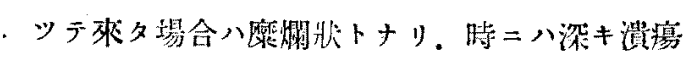

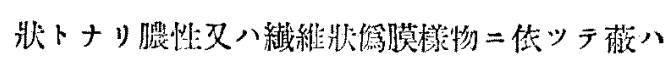
ル、二至ル事アリ。而シテ遂ニハ Schäffer， 云ヘル如ク直接「グム、性微素二移行シ表面八

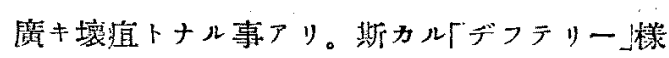

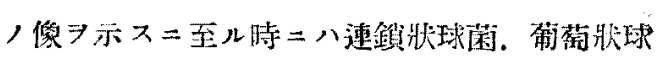
菌又八肺炎球菌ノ混合感染习來夕セル時アリ。 又圆形ニシテ周圍二風園ニト圆キ環タナシテ揣 ガレルトキニハをヨ環版型 (annulare, circinae)ト程ス。斯カルトキ二八乳頭八次第二消失

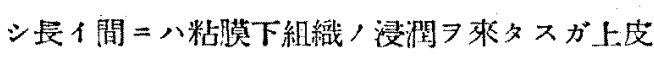
ニ八餘り變化 $尹$ 呈シナイ。而シテNeumann 八 斯カル型モ，極メテ再發シ易ク遂二ハ「ダ ムマ」形成 7 營ムニ至ルト云つ。又他ノ型トシ テ舌八淡キ灰色/般痕 頸部淋巴腺，腫脹ラ隶タ又場合モアり。

八. 符三期微毒。

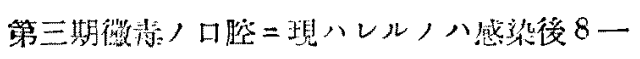
15年ニシテ現ハレル事が最モ多ク．早イモノ八 極メテ稀=4ー5ケ月ニシデ出現スルモノモア

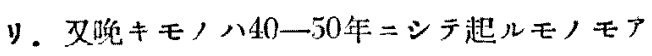
1).

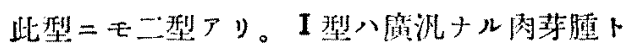
シテ來ルモノデ，I型八卧局性二發垷スルモ， デアル。表面二近名在スル場合ヨリ又八深 部二發生スルモうモアリ。文其經過八船狠性葲 縮，让態トナルモノアリ。文八特有ナル「ダム

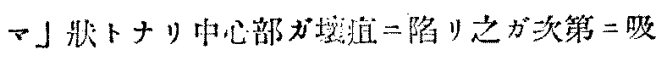

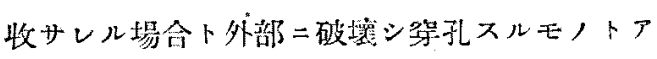

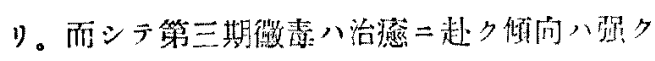




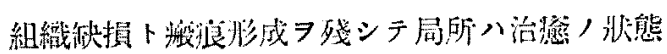
$ト ナ ル 。$

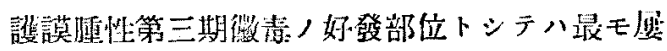

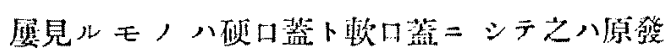

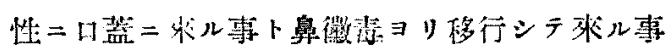
トアリ。Tournier $>40000$ 例/第三期微毒㭧者 二於于硬口盐二病變习來タ七ルモ/ $5.0 \%$ 。㜞口 蓝ノモノ $2.5 \%$. 舌ノモノ $5.7 \%$ 見タりト派ズ。

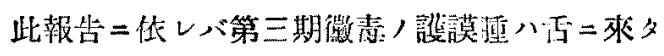
ル事最モ多タ次二硬口盖。歌口笽，順トナル。

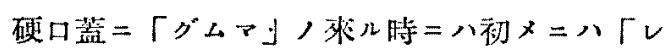
ンズ」大ョリ扁化大ノ軟イ赤色ノ膨隆トシテ杫

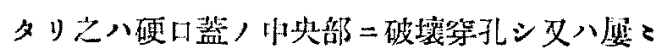
突然舆腔，方二破壞シ空洞习形成ス几事アリ。 斯カル變化八粘膜ヨリ始マル事モアルガ爻八口

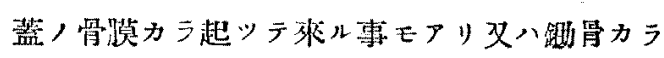
起ッテロ蓝二穿孔シテ爽ル事モアリ。

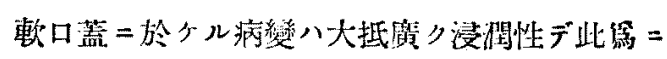
口蓋帆ハ堅クナリ暗赤色二肥厚シ照垠垂モ亦肥 厚シ太クナル。例シ乍ラ硬口篮ト八比較的判然 卜境界将レ硬口塕八稍に荅白二見ラレル。而

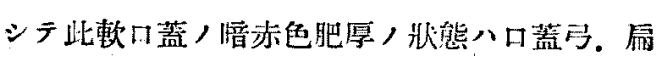

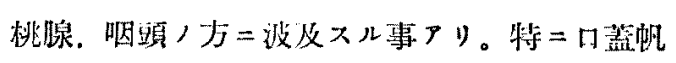

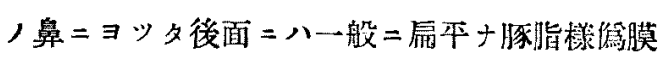

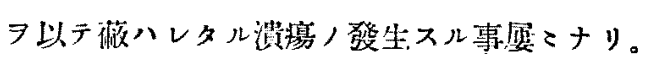

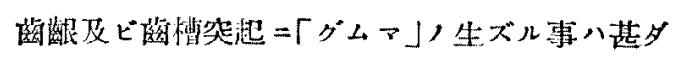

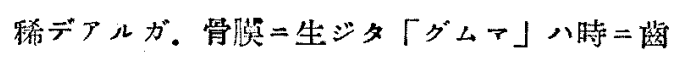

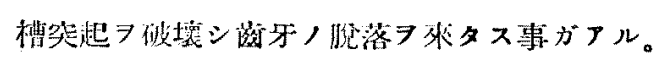

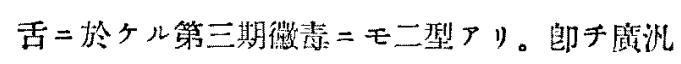
ニ來ルモ，ト限局性ノモノトアリ。限局性，モ 八八粘膜下二來儿事卜，深部，淋巴腺=發生 $ᄌ$

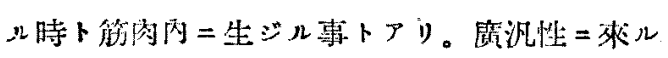

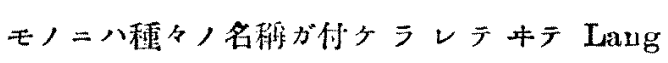

八 Glossitis interstitialis luetica 爻八Glossitis cicatricans ト稱シ. Zeisse 八 Glossitisinduratira diffesa ト記シ, Mauriac 八 Glossitis schrogummosa diffusa $ト$ 程ス。燩汎性 二來ルモノモ亦深部 =侵入スル型卜表面性ノモ ノトノ 2 種アリ。染部二侵入スル梨ノモノデ八

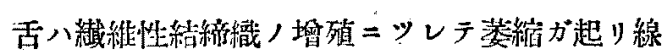

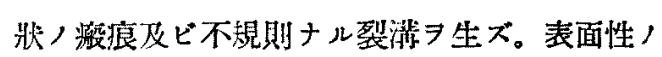
モノデ八平滑ナ赤色，斑トシテ現ハレ初期感染 ，病像卜甚ダ類似セルガ多クハヨリ本㳻ニシテ 限界モ稍に制然ト七ズ著シク硬固ナリ。而シテ 粘膜下二浸潤强り乳頍八消失シ䉆二上皮八平滑 二見ユ。之八後二八淺在性ノ搬痕トナリ舌ノ表

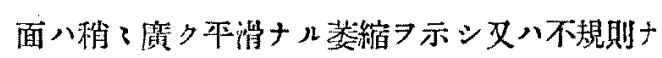

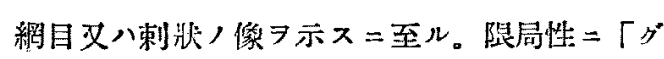

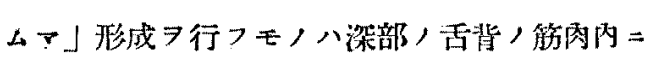
好發ス。故二初メハ殆ンド外面ヨリ晃ラレザル 事多シ。後二八舌背，粘膜苏膨隆シ來タり遂二 八上皮が缺損スル二至り中心部軟化シ第孔スル 二至儿。此場合八底部二凹凸不平ナル芽 見. 其第孔彩い深ク陷入シ銃っ境界サレタル溃 疼ア形成 スル二至ル。其大》八約拇指頭大ヨコ 䴓卵大二テ其數八單發，事アリ又多數储發スル 事厂リ。

護謨偅ノ舌下面二生ズル事八極メテ稀トサル。 口磿二モ護謨睡/來几事つリ。此場合へ女子ヨ 1) 男子:多ク之八煙营 7 吸つ事が誘因トナルモ ノナリ. Lieven ハ250例，第三期徽青㭧者中4

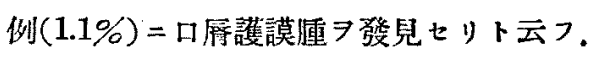

二. 余，庭例=對ス几考察。

余，症例八腎者八初メ八微毒二䍜リシ事习否 定シ䛨シク問診习續タタルニ。昨年11月頃感染 ノ機會アリシ事フ告白シ。少ホョク問診七ル 
12月=至り陰萑二小硬紿ノ生ジタルコトヨ思上 起シテ告白セリ。今迄八患者八全ク其硬結力徨 表ナリシ事三八氣ガ付カズ經過セルモノナリ

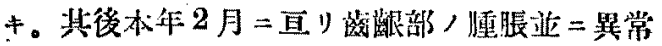

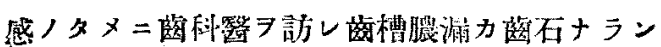

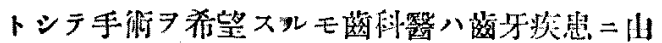
ルモノニ非ズト云七何等カノ他, 疾患 7 疑へル モ診斷ハドシ得ズ患者二他/醫二診斷 漛注意七ルモ．其後患者ハ大シテ苦痛ナキタメ

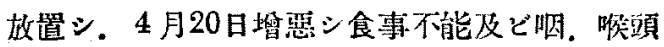
，絞扼感フルニ及ビ整キ本外科フ訪レタルモ， ナリ。此經過ヨ考へ見ル二鼿手感染機會ヨリ約 4 週ニシテ陰部二初期硬綪アルニ㴋的キ感染後

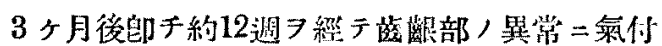
キタルモノニシテ其後約 2 ケ月ニシテ突發的二

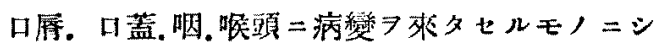

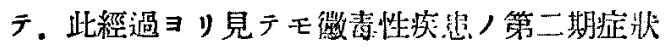

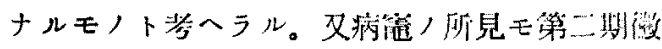
站: 质骖(Papel) =シテ plaque muqueuse.

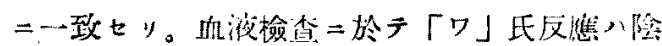
性二終りシモ弗出氏父應。村时氏反應八陽性卜

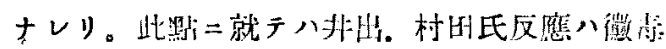

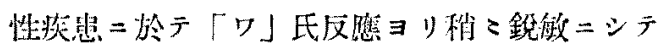

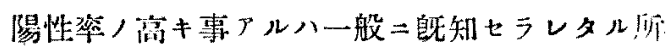

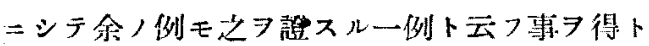
思ハル。

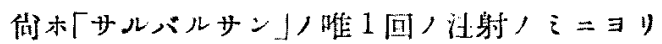

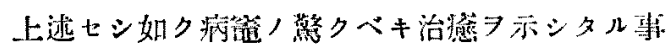

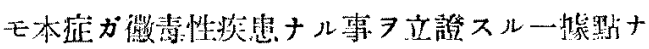
リト云フヨ得ペシ。

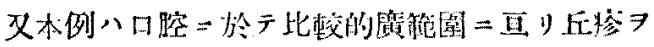
生ジタル例トシテメ各部二於ケル第二期微表，

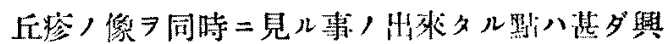
味アル例ト思八ル。

\section{（三）局．紅．苔，ト口腔第二期徽毒 (丘疹型) トノ區別 並二口腔內他疾患卜ノ主ナル鑑別二就テ}

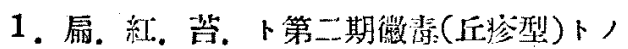
鑑別。

扇，紅，苔。卜第二期微青， plaque muq-

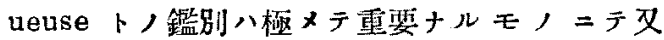
霆 こ困難ナルモノ：屬ス。幸二余八最近煩部粘 膜. 軟口蓋. 缹峎及ビ舌下面 $=$ 稍

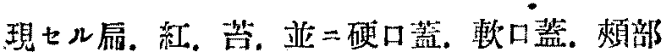

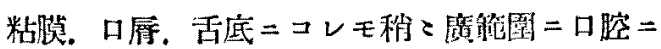
發現七ル第一期徽素:シテ Plaque mucaueus

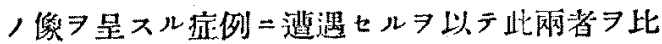
較シテ其局所所見，差暴厂几所 7 逃べ显二一般

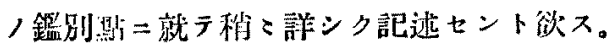

先ヅ第一二其發垉部位ヨり述プレバ䲩，紅。苔。 八口腔䉼膜二現ハレル時二八媔部粘膜，口解部 特=第 2 大回落，附近二登生スルコトが上述七 シ如ク Trautmann 茂ビ Jadassohn =依レバ

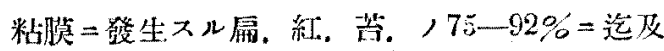
ブト云フ。然王對照的二网側二發生ス几事八特 二特長アルモ，ト思八ル。次二多ク琶八ル、部

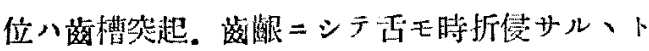

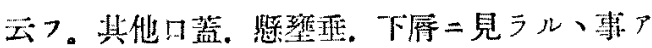
リト云つ。plnque mutieus，發現スル部位八

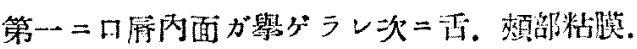

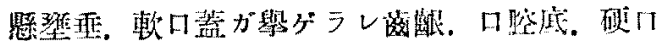


蓋八比較的稀レトサル。

余，例 $=$ 於テ，扁. 紅。苔，，症例二於テ八極 メテ徐々二最初在頓部粘膜，日解部二初發シ。 之ガ右侧偭部粘膜，口触部二モ續發シ舌下面.

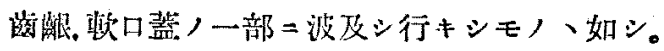

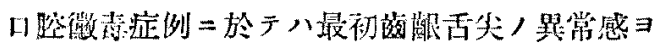

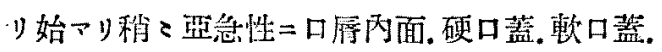

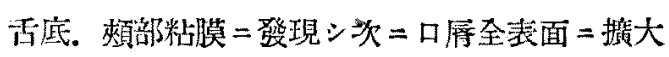

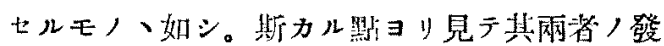
生焆態並二部位二於テモ各に稍 異ナレル點ア リト思ハル。即チ扁.紅. 苔.ニテ八其發生が㥛メ， テ徐タナル事及ビ刃煩部粘嗼ニシテロ解部特ニ 第 2 大目缹，部二初發シ。然业照的ナル事力

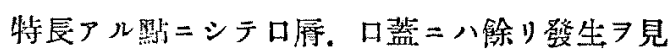
ザル事。plaque muqueuse 八場合二八初メ硬.

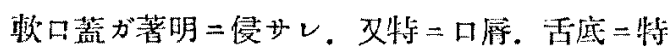
長アル病篗习發現セル八與味アル默卜思ハル。 次二粘膜，所見 $ョ$ リ見レパ．余，經驗七儿爾症 例二於テ特二强り其网者，局所所見ヨリ見テ異

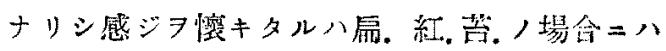
其全能，感湆が極メテ表面的ニテ一種，光:罢》 有シ. Hallopean，云へル如ク「オプラート」 樣白玟ナル然にシシテ. 此形容八賽ニヨク口腔粘

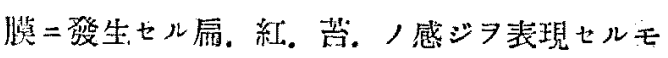
，ト思ハル。 plaque muquense，場合二於テ

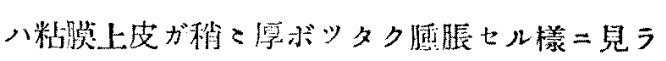

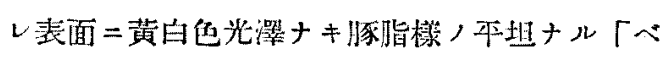

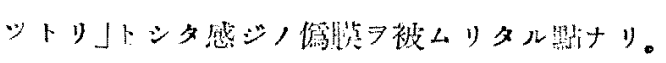

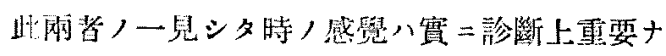

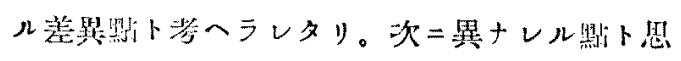
ハレタル八扁. 紅. 管. ニ於テ八精絸=見レぶ

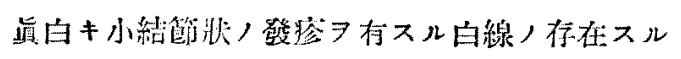

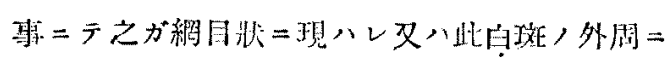

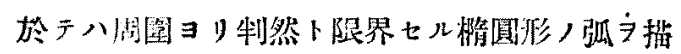

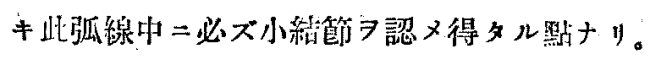
plaque muqueuse =柉广ハ口盐二於ヶル所見

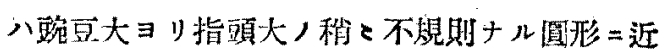

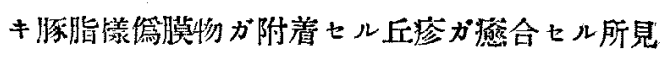

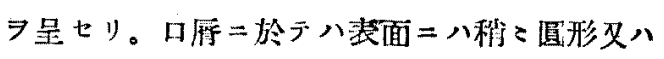

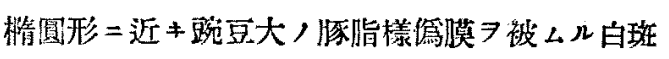
ヨリ口原內面ノモノ八三解形风八長方形ノ稍 大ナル斯カル白斑ヨ認メ其周圍二八制然卜赤色 ノ量フ認メ得タッ。顂部粘膜二於テハロ角部及 ビ䔄列二沿七頓部粘膜，秒 ，秒? 肥厚膨隆シ。其上二稍 $、$ 厚ク白 + 不透明

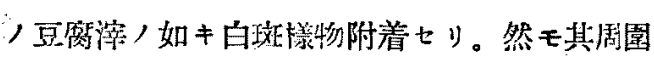

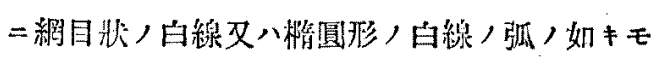
ノョ認メズ，羽圍粘膜卜，境界八判然ト七ズ。

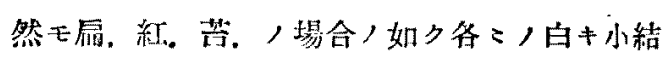

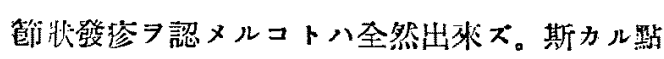

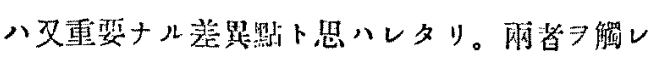

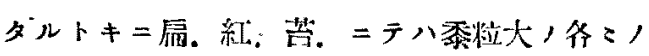

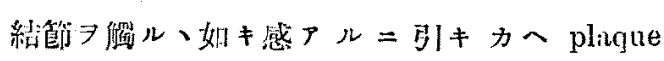
muquense，場合二八軟骨㧼，抵抗 7 感ジタ リ。次二重要ナルハ斯カル白斑，周園粘膜，像 ニシテ扇. 紅. 简.，場合二於テモ二次的變化卜 シテ「アフタ」㥞白玟フ生ジタルトキ小其「フフ

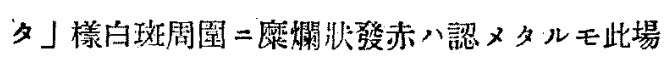
合二八其周圍稅 カル二㳄的變化 7 伴ハザル部位=於テ八䒩然周 国二登赤ハ見ラレズ然モ其境界八粗目爿白線又 八弧䠌=ヨリ判然卜區别七ラレタリ。

plaque muqueuse =於テハ口篮部=於テモ各

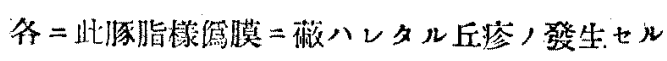
場合二八日嘚卜同栐=周園二著明ナル赤色晕 镍メラレタリ。䫪部粘膜=於テハ乳白色，極メ 


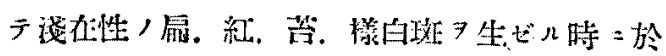

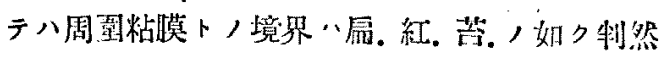

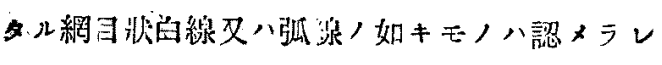

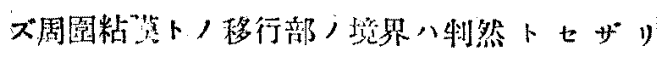
$\neq$.

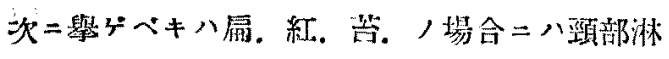
巴腺，腄脹ヨ見ザリシモ。第二期微靑症例 = 於

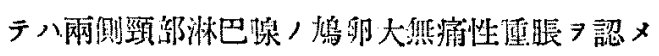

\section{タリ。}

次二一般的常識的，區別トシテ余，症例 =㞶テ

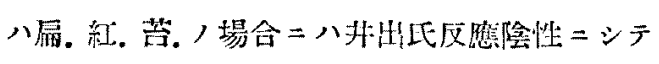
「口」氏反隹及ビ村时氏反應、2回＝亘り檢查七 ルモ陰性ナリキ。微表症例＝於テハ州出氏反應 中等度陽性. 村时氏反應喝性ナルモ「ワ」氏反應 八陰性二終レリ。併シ乍ラ扇. 紅. 装.，場合= 於テ今迄，症例派告中二小「口」民反應陽性ナり シ報告八時折見ラレ森时，1例二於テモ陽性ナ

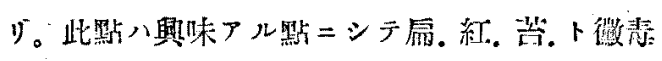

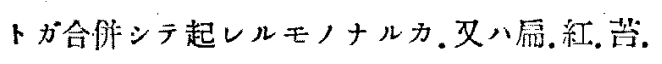
ナル疾病が其病因二於示何等力，微素卜，近似

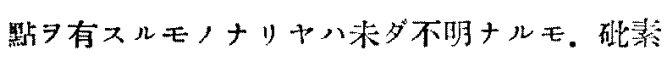
劑，內服又い「ルバルサン」，注射が可成り ，程度二迄有效二作用スル點ヨ見レバ德素卜何 等カ，因果關係习有スルモノナラント思ハル。

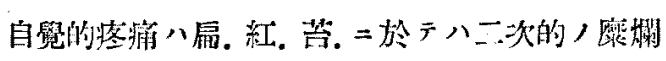

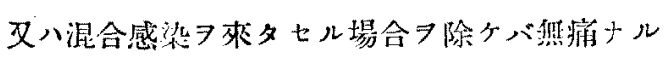
习监通卜スルニ。余，例二於テハ二次的二頓部

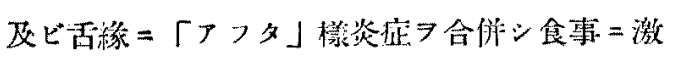
シキ疼痛习游へタリ。微青症例 =於テモ一般=

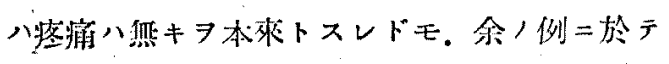

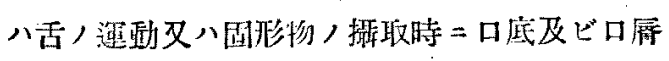

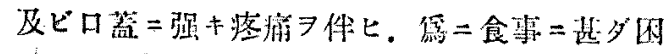
鞋 7 感ジネレリ。

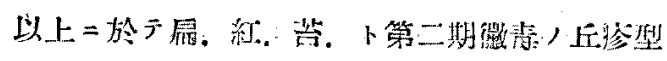
(plaque mucneus) $ト$ ，余，䋑驗七几证例 =

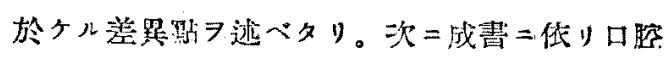
二發生スル数似疾患，䤵別 7 略記セントス。

2. Lencoplaxie ト.鑑则。

Leucoplaxio =於テハ虚讯=シテ上皮八白色

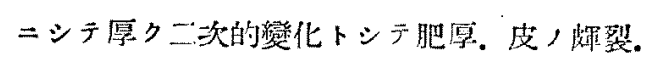
糜瓓 ヨ來タス。

3. Lupus erythematodes.

Lups erythematodes ト L. r. p. 卜 人鑑别 八稍 楾方現ハルL. erythematodes，場合二八細線 八白琣上=向ツテ放線将トナル。 L. r. p. ノトキ

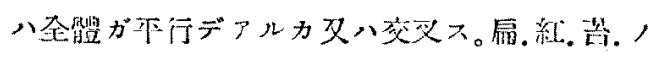

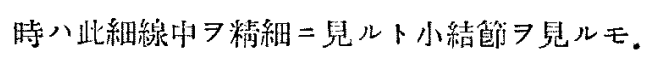
L. eryth. ノトキ八單二平等十儿上皮，肥厚

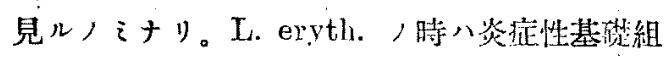

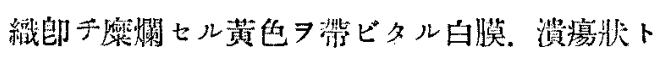

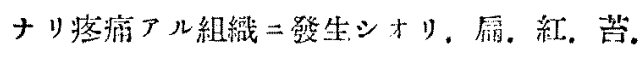

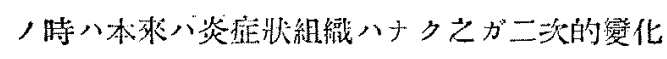

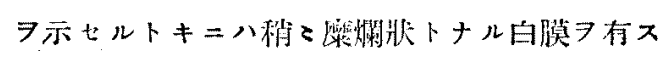
ルコトモリ。

4. Epidermolysis bullosa hereditaria.

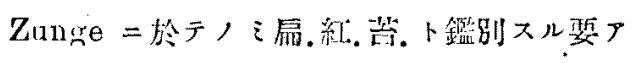
リ。特二 Leukoplaxie 樣/肥厚ヨ呈シタル時 ニ八此必要ヨ生ゼルモ未期二ナレパ $\mathrm{E}_{\mathrm{p}}$. bull Osa八再三水泡形成スル二至ルタ又區別八容易 トナル。 


\section{（四）結}

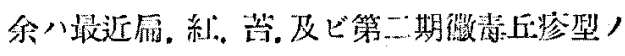
2 症例二遭遇七リ。

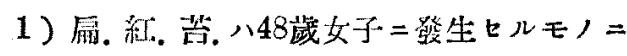

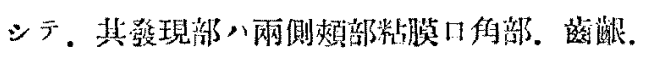

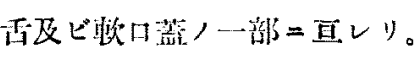
治漝法トシテ吪等/雨服及ビ「サルバルサン」 注射八或程度选有效二作用セルモ全治シ得ズ。

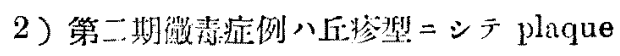

\section{范侖}

mucaeus /像

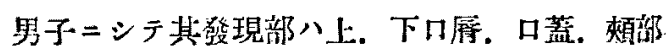
粘膜, 舌底二及ベリ。

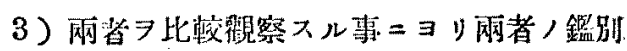

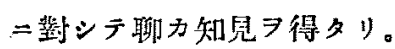

4) 兩諸, 局所所見 7 模寫シ得タル 考二俱スル炏第ナリ。

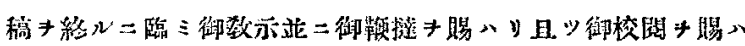

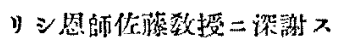

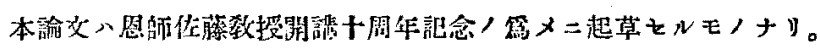

\section{文献}

1) Krem: Mont. f. Ohrheil. 1910. Bd. 44. S. 93. 2) Eliusberg: M. f. O. 1913 Bd 47. S. 816 . 4) Fein: M. f. O. 1914 13d. 48 S. 435 . 4) Brnek: M. f. O. 1914 Bd. 48 S. 1030 . 5) Haslinger: M. f. O. 1925 Bd. 59 S. 1035 . 6) Ntaschiek: M. f. O. $1925 \mathrm{Bd} .59$. S. 1035.7$)$ rreinal: M. f. O. 1921 Bd. 55.S. 166. 8) Huttex: M. f. O. 1911 Bd 45. S. 654. 9) Grosglik: M. f. O. 1914 Bd. 48 S. 1345. 10) Kiess: Dermatolog. Zeitschrift 1921. I3d. 33. S. 140. 11) Franz v. Poor: D. Z. O. Lasser Band XII 1995. S. 641. 12) Denker u. Kabler: land IV. 13) v. Mikulez u. KiinnmeI: Die Kht des Mundes 1922 . 14) Riedke: Lehrbuch d. Der. 1912. 15) mayes: Clinical Diagnosis of disease of the Month. 1986. 36) williger: Viertel Jahresschrift für Zahnlreilkunde 192t. S. 58 17) Seider: Zeitschrift für Itomatologie 1936 Bd. 24 S. $101 t$ 18) Broca : Dental Koosmos 1919 bd. 61 S. 905. 19) Malafeck: Zeitschrift Stomatologie 1937. Dd. 35.20 )
Minder: The Journal of American Denlal Asoc. 1931 Bd. 12 S. 2357 21) Liberthal: T. i. o. A. D. A. 1907 . Bd. 24. 22) Henke w. Muharseln: Handbuch d. Speciellen Path. Aat. Bd.

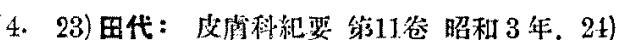
中野：皮虔泌尿誌 第15犖 162頁大正15年，25)

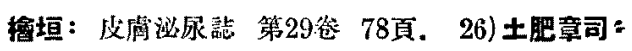

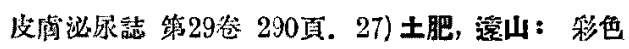

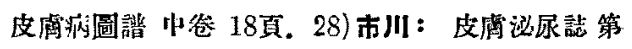
33替 530頁昭和 8 年. 29) Chipman: T. J. o. A. D. A. 1918 . Bd. 16. 30 ; 山本：农陾泌尿誌第36

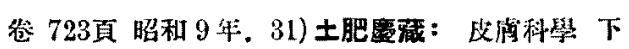

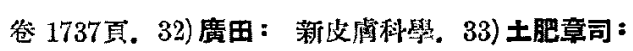

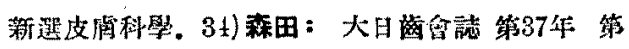

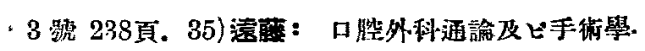

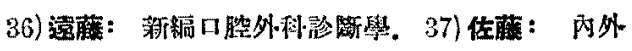

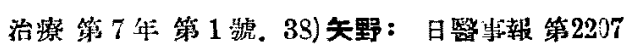
歎. 39) Cemacln: Differencial Diagnose d. Mund, Rachen u. Kehlkopfkht. 40) Denker a. Albrecht: I.ehrbuch d. Kht d. Ohres u. Luftwege. 


\section{尾 形論 文附圖}

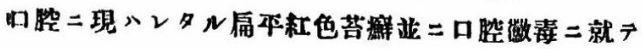
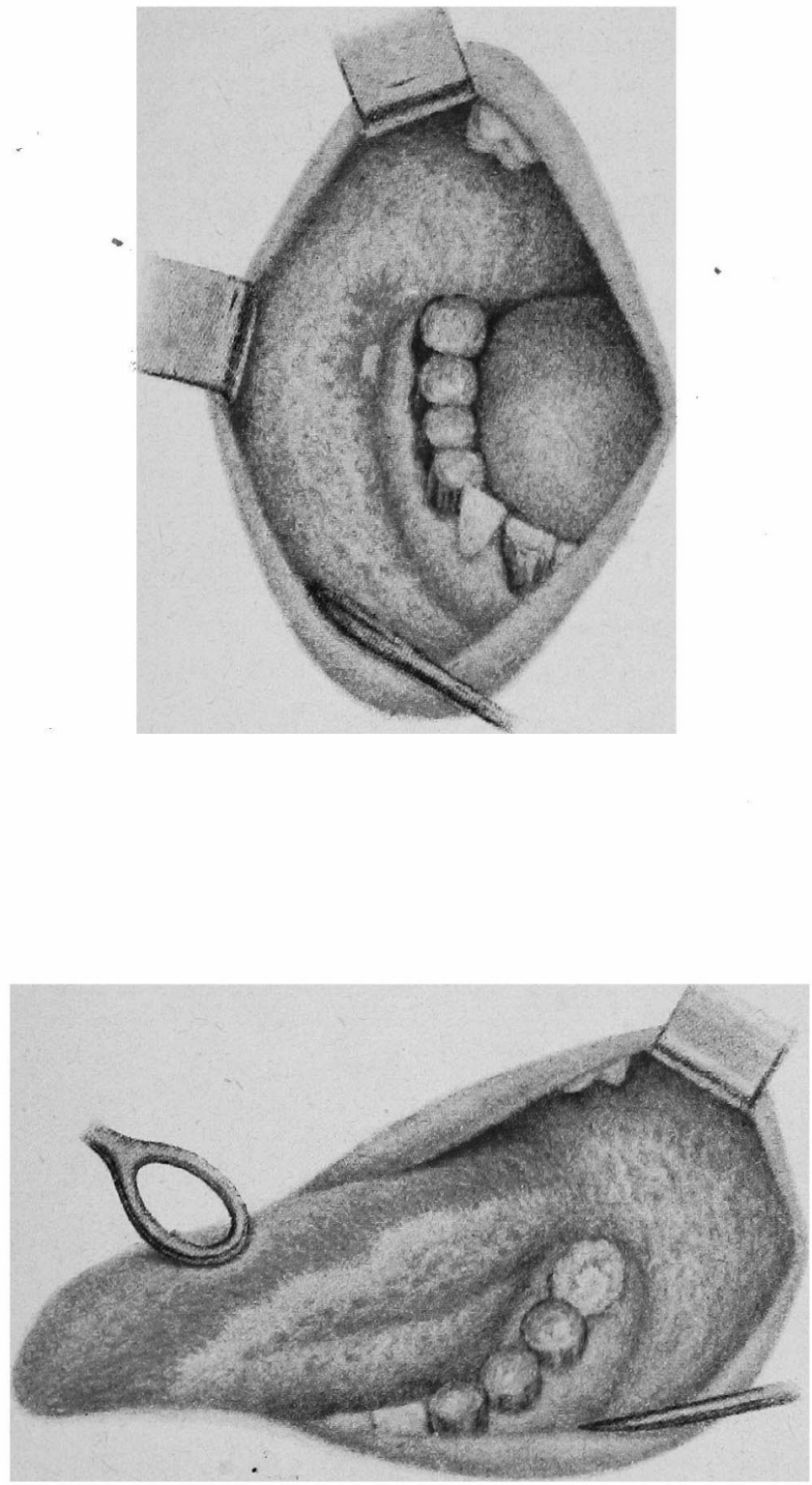

Dr, Mamorn Ogata: Úber Líchen ruber planus und plaque muqueuse an Mundhöhleschleimhaut. 